\title{
Spiders from the Ionian islands of Kerkyra (Corfu) and Leflkada, Greece (Arachnida: Aranei)
}

\section{Пауки Ионических островов Керкира (Корфу) и Аевкада, Греџия (Arachnida: Aranei)}

\section{Anthony Russell-Smith \\ Э. Рассек-Смит}

1, Bailiffs Cottage, Doddington, Sittingbourne, Kent ME9 0JU, the UK.

KEY WORDS: Aranei, Greece, Ionian islands, faunistic list.

КЛЮЧЕВЫЕ СЛОВА: Aranei, Греция, Ионические острова, фаунистический список.

ABSTRACT. A list of spiders collected from the Ionian islands of Kerkyra and Lefkada is provided together with a list of all previously published records. Information is provided on collection localities, habitats and geographic distribution of all species recorded. A total of 94 species were collected in Kerkyra, of which 37 had not been previously recorded. 98 species were collected in Lefkada, of which 71 were new records for the island. Currently, 243 spider species are recorded from Kerkyra and 117 species from Lefkada. Five species collected were new records for Greece: Agyneta mollis, Tenuiphantes herbicola (Lefkada), Trichoncus sordidus (Kerkyra), Tmarus stellio (Kerkyra) and Xysticus cor (Lefkada). The results are discussed in relation to similar studies on other Greek islands and it is concluded that the fauna of both islands remains poorly known.

РЕЗЮМЕ. Представлен список пауков, собранных с Ионических островов Керкира и Левкада, вместе со всеми более ранними указаниями. Дана информация о точках сборов, местообитаниях и географическом распространении всех отмеченых видов пауков. Всего приводится 94 вида пауков с острова Керкира, из которых 37 видов найдены впервые, и 98 видов с острова Левкада, из которых 71 вид наден впервые. В настоящее время с острова Керкира известны 243 вида пауков и с острова Левкада 117 видов. Пять видов отмечены впервые для фауны Греции: Agyneta mollis, Tenuiphantes herbicola (Левкада), Trichoncus sordidus (Керкира), Tmarus stellio (Керкира) и Xysticus cor (Левкада). Результаты обсуждаются в сравнении с данными похожих исследований пауков на других греческих островах. Сделан вывод, что фауна пауков обоих исследованных островов остается плохо изученной.

\section{Introduction}

Despite much recent work on both the systematics and faunistics of the spiders of Greece, our knowledge remains limited compared to that for most of central and NW Europe, as is the case for all areas of the eastern Mediterranean. An important recent advance was the publication of an annotated catalogue of the Greek spider fauna [Bosmans \& Chatzaki, 2005]. This listed a total of 856 valid species for the country, although that figure has been substantially increased by subsequent work. Since then, provisional checklists have been published for the islands of Lesbos [Bosmans et al., 2009], Chios [Russell-Smith et al., 2011] and Crete [Bosmans et al., 2013]. These checklists apart, there has been little published on the spider faunas of individual regions of Greece.

Kerkyra: known in the English-speaking world as Corfu, has been a favoured holiday destination for visitors from northern Europe since at least the middle of the $19^{\text {th }}$ century. Perhaps partly as a consequence, exploration of its spider fauna began earlier than in many other areas of Greece. The earliest published spider record for the island is for Cyrtocarenum cunicularium by Doleschall [1852]. Between that date and the beginning of the 20th century, over 50 species were recorded by A. Ausserer, L. Koch, O. Pickard-Cambridge and E. Simon. The last author accounted for $70 \%$ of these, including type material of six currently valid species. In the first half of the 20th century, W. Bristowe [1935], L. Giltay [1932] and E. Reimoser [1930] added a further 50 species to the list of which just under half were recorded by the last author. During the post-war period, emphasis shifted away from purely faunistic recording towards studies of particular taxa or specific habitats within the Mediterranean region. During this period, the most important contribution was made by P. Brignoli [1976-1984] who added 27 species, particularly from the many caves in the northern half of the island. Deeleman-Reinhold \& Deeleman [1988] recorded 15 species of Dysderidae from the island as part of a much wider revision of the family in the eastern Mediterranean region as a whole. As a result of the work of these and many other authors, the number of spider species recorded from the island stood 
at 208 as of January 2014 (Appendix 1). This figure is considerably higher than those for the much larger islands of Lesbos (43 species) and Chios (27 species) prior to the publication of the surveys by Bosmans et al. [2009] and Russell-Smith et al. [2011].

By comparison with Kerkyra: the recording of spiders from the smaller island of Lefkada started much later and the island has been visited by relatively few arachnologists. The first records for the islands were published by E. Reimoser [1930] who listed 21 species. In a second paper, the same author added a further 31 species [Reimoser, 1958]. Very few other authors have published records for the island so that a total of only 54 species had been recorded as of January 2014 (Appendix 2).

The spiders included in this paper were collected during short visits to Lefkada in May and June 1993 and 1995 and to Kerkyra in May and June 1999 and 2000.

\section{Study area and methods}

The two Ionian islands of Kerkyra (Corfu) and Lefkada (Lefkas) lie to the $\mathrm{W}$ of the Greek mainland. Kerkyra $\left(593 \mathrm{~km}^{2}\right)$ to the North is the seventh largest and Lefkada $\left(303 \mathrm{~km}^{2}\right)$ is the 14th largest of all Greek islands (Maps 1-2).

The north-eastern coastline of Kerkyra $\left(39^{\circ} 37^{\prime} 6^{\prime \prime} \mathrm{N}\right.$, $\left.19^{\circ} 54^{\prime} 26^{\prime \prime} \mathrm{E}\right)$ lies off the coast of Albania, from which it is separated by straits varying in width from 3 to 23 $\mathrm{km}$ ( 2 to 14 miles), while the south-east side of the island lies off the coast of Greece. Two high and welldefined ranges divide the island into three districts, of which the northern is mountainous, the central undulating, and the southern low-lying. The more important of the two ranges, Pantokrator, stretches east and west from Cape Falacro to Cape Psaromita, and reaches its greatest height $(911 \mathrm{~m})$ at Mt. Pantokrator. The underlying geology is largely limestone with smaller areas of sandstone and clay.

Lefkada (38 $\left.49^{\prime} 39^{\prime \prime} \mathrm{N}, 20^{\circ} 42^{\prime} 07^{\prime \prime} \mathrm{E}\right)$ lies between Kerkyra to the North and Kephalonia to the South. Very close to the western part of mainland Greece, Lefkada is connected to the mainland with a small 50-meter floating bridge. The geography of Lefkada is mountainous, with narrow fertile plains near the coast. The highest peak is Mount Elati (1158 m a.s.1.). As in Kerkyra, the underlying geology is principally limestone with some soft quaternary deposits in valleys and near the coast.

The climate of both islands is typically Mediterranean with hot dry summers and cool wet winters. However, Kerkyra and Lefkada have relatively high rainfall compared to most other Greek islands. Annual average rainfall for Kerkyra $(1020 \mathrm{~mm})$ is almost twice that for Heraklion in Crete $(540 \mathrm{~mm})$ and continues longer into the early summer (Fig. 1). In addition, winter temperatures for Kerkyra are about $2^{\circ} \mathrm{C}$ higher than those in Crete. As a consequence, the Ionian Islands are exceptionally green and have an extended growing season compared with islands in the Aegean Sea and further South.

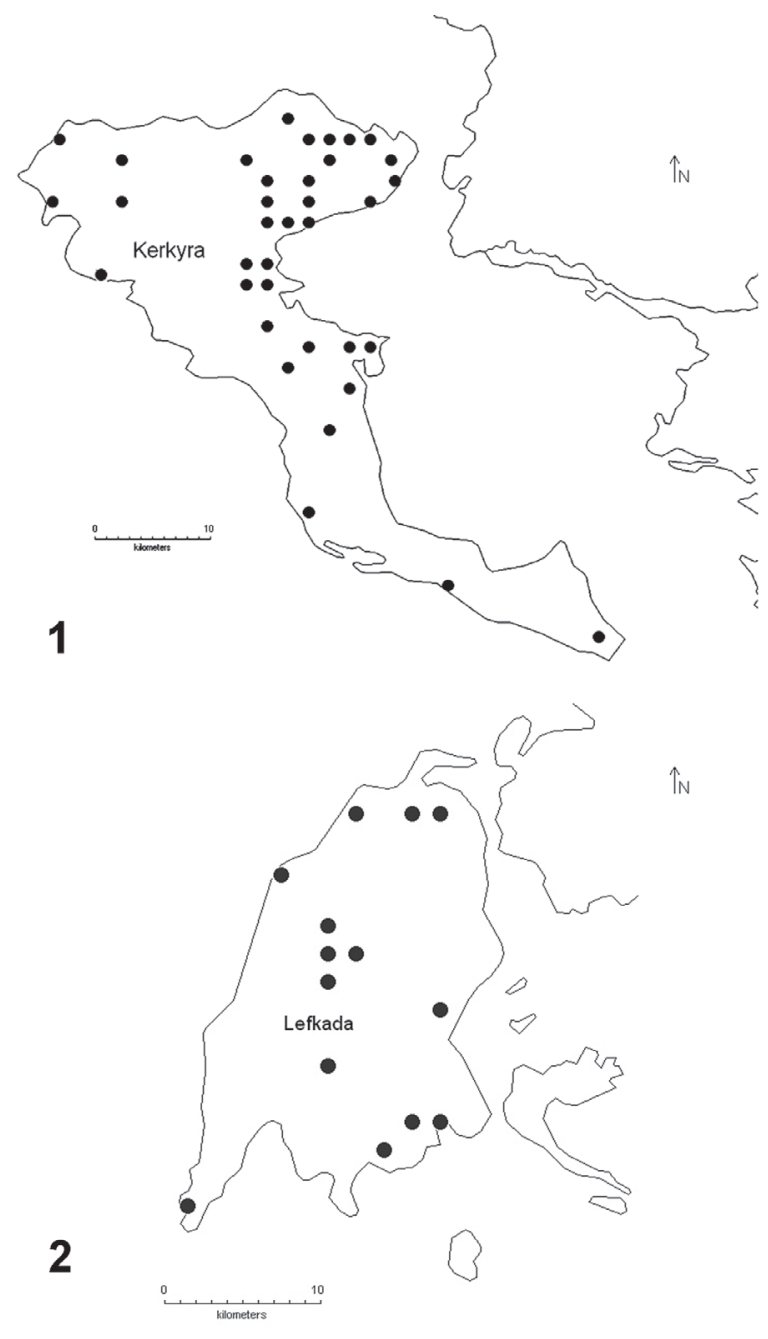

Maps 1-2. Maps of Kerkyra (1) and Lefkada (2) showing all known collecting localities for spiders.

Карты 1-2. Карты островов Керкира (1) и Левкада (2), показывающие все точки сборов пауков.

The majority of collecting was done by hand with a limited amount of beating of shrubs and trees. On both islands, the principal habitats sampled included shady olive groves, Mediterranean phrygana (equivalent to garigue in other parts of the region), and maquis. Some collecting was also done on coastal sand dunes, cliffs and in riparian vegetation along streams.

All specimens included in this study were collected by the author and are deposited in The Manchester Museum, University of Manchester (accession number: G7548).

\section{List of species}

\section{Family AGELENIDAE}

Maimuna vestita (C.L. Koch, 1841)

MATERIAL. Kerkyra: 1 , Mt. Pantokrator, under stones in phrygana. 29.05.1999; 3 + , path between Kerasia beach and Kala$\mathrm{mi}$, in phrygana, 26.05.1999; 1 \% , Agios Stephanos, under stones in 


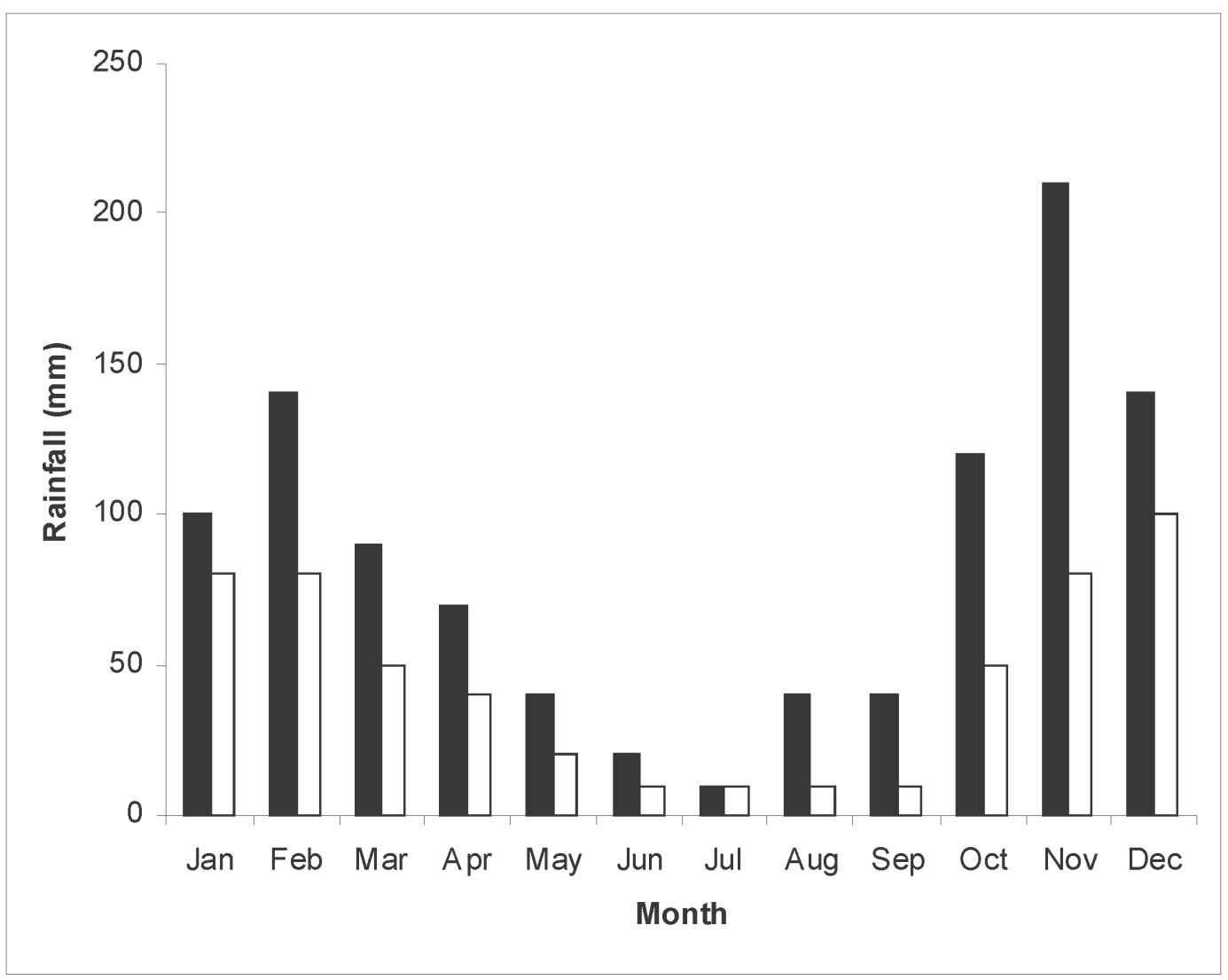

Fig.1. Monthly average rainfall for Kerkyra and for Heraklion (Crete). Shaded bars for Kerkyra and unshaded for Heraklion.

Рис.1. Месячные осадки на острове Керкира и в Гераклионе (Крит). Темные колонки - Керкира, светлые - Гераклион.

olive grove, 1.06.1999. - LEFKADA: 1 , Mikros Ghialos, on rocks behind fishing port, 1.06.1995; 1 , beach at Agios Akitas, in marram grass, 27.05.1995; 3 우, valley behind Mikros Ghialos, under stones, 26.05.1995.

DISTRIBUTION. A widespread and common species in Greece, as it is throughout the eastern Mediterranean. Females were always collected in small webs beneath stones.

Tegenaria regispyrrhi Brignoli, 1976

MATERIAL. KERKYRA: 5 O9, Kerasia beach nr. Agios Stephanos, under stones in olive grove, 25.05.1999; 2 O+, $2 \mathrm{~km}$ from Agios Stephanos, in olive grove, 30.05.1999; 1 \%, Agni, in olive grove, under stones, 2.06.2000. Det. A. Bolzern.

DISTRIBUTION. Bulgaria, Macedonia and Greece.

\section{Family AMAUROBIIDAE}

Amaurobius sp.

MATERIAL. KerKyra: 1 , house nr. Agios Stephanos, under stones, 3.06.1999.

COMMENTS: Females of Amaurobius species from this region cannot be identified with certainty [Thaler, Knoflach, 1998].

\section{Family ANYPHAENIDAE}

Anyphaena sabina L. Koch, 1866

MATERIAL. LEFKADA: 3 오, W of Mikros Ghialos, beaten from shrubs, 25.05.1993.
DISTRIBUTION. Europe, Turkey, Russia, Georgia, Azerbaijan. Recorded from Greece only in Lesbos, Chios, Crete and Kerkyra. New to Lefkada.

\section{Family ARANEIDAE}

Cyclosa sierrae Simon, 1870

MATERIAL. KERKYRA: $10^{7} 2$ 우, path from Kerasia beach to Kalami, in phrygana, 26.05.1999; 1 , between Agios Stephanos and Koulouri, on rocks in cove, 6.06.1999; $1 \mathrm{O}^{\top}$, Agios Stephanos, on wall of house, 3.06.1999. - LeFRADA: 3 ox, top of cliffs at Porto Katsiki, on shrubs in phrygana, 31.05.1993; 1 \% , nr. Poros, beaten from shrubs in phrygana, 5.06.1995.

DISTRIBUTION. It is distributed from southern Europe eastwards to Georgia. A widespread species throughout Greece but new to Lefkada.

Gibbaranea bituberculata (Walckenaer, 1802)

MATERIAL. LeFKADA: 1 , W of Mikros Ghialos, in grass, 22.05 .1995

DISTRIBUTION. Throughout the Palaearctic from Europe to Siberia and Japan.

Glyptogonia sextuberculata (Keyserling, 1863)

MATERIAL. LefKADA: $10^{7}$, W of Mikros Ghialos, under stones in olive grove, 23.05.1993; 1 , , valley behind Mikros Ghialos, in long grass, 1.06.1995.

DISTRIBUTION. Italy, the Balkans, Greece, Turkey and Israel. There are scattered records across much of Greece but new to Lefkada. 
Mangora acalypha (Walckenaer, 1802)

MATERIAL. KeRKYRA: 1 \%, Agios Stephanos, among stones in olive grove, 1.06.1999. - LefKadA: 1 Or $^{7} 3$ 우, W of Mikros Ghialos, in grass in olive grove, 23.05.1993.

DISTRIBUTION. Widespread and abundant throughout Greece and across the Palaearctic region as far as NW China.

Neoscona adianta (Walckenaer, 1802)

MATERIAL. KeRKYRA: 1 , S of Avlaki, beaten from giant heather, 3.06.2000. — LEFKADA: $1 \sigma^{7}, \mathrm{~W}$ of Mikros Ghialos, beaten from shrubs, 25.05.1993; $2 O^{7} \sigma^{7}$, valley behind Mikros Ghialos, in long grass, 1.06.1995; $1 O^{7} 1$, Mikros Ghialos, in grass behind fishing port, 1.06.1995; $3 \sigma^{7} \sigma^{7}$, nr. Poros, beaten from shrubs in phrygana, 24.05.1995.

DISTRIBUTION. Widespread and abundant throughout Greece and across the Palaearctic region. New to Kerkyra.

Neoscona subfusca (C.L. Koch, 1837)

MATERIAL. LefKada: 2 우, top of cliffs at Porto Katsiki, on shrubs in phrygana, 31.05.1993.

DISTRIBUTION. Throughout much of the old world and with scattered records across Greece. New to Lefkada.

Zygiella x-notata (Clerck, 1757)

MATERIAL. Kerkyra: 1 q, between Agios Stephanos and Koulouri, on rocks in cove, 6.06.1999.

DISTRIBUTION. A very widespread Palaearctic species with scattered records from most regions of Greece.

\section{Family CORINNIDAE}

Phrurolithus szilyi Herman, 1879

MATERIAL. Kerkyra: 1 +, Agios Stephanos, under stones in olive grove, 1.06.1999. - LefKADA: 19 , nr. Nidri, in thick grass in meadow, 2.06.1993

DISTRIBUTION. Central and southern Europe. In Greece only previously recorded from the Pelopponese.

\section{Family DICTYNIDAE}

Dictyna latens (Fabricius, 1775)

MATERIAL. Kerkyra: 1 , between Agios Stephanos and Koulouri, on rocks in sea cove, 6.06.1999. - LEFKADA: 3 우, nr. Poros, beaten from shrubs in phrygana, 5.06.1995.

DISTRIBUTION. A widespread Palaearctic species extending from Europe to central Asia. The commonest species of Dictyna in Greece. New to Lefkada

Nigma puella (Simon, 1870)

MATERIAL. Kerkyra: $10^{7}$, Kerasia beach, Agios Stephanos, under stones in olive grove, 25.05.1999.

DISTRIBUTION. A West Palaearctic species. There are only two previous published records for this species from Greece, on the mainland in Evvoia and from the island of Chios.

\section{Family DYSDERIDAE}

Dasumia cephalleniae Brignoli, 1976 ?

MATERIAL. Kerkyra: 1 , Kerasia beach, Agios Stephanos, under stones in olive grove, 29.05.1999. - LEFKADA: $1 \mathrm{O}^{\top}$ ?, W of
Mikros Ghialos, under stones, olive grove, 25.05.1995. Det. C. Deeleman-Reinhold.

COMMENTS. The male of Dasumia cephalleniae has yet to be described. Until the male and female are firmly associated the identification remains tentative.

DISTRIBUTION. A species endemic to Greece but which has not been previously recorded from Kerkyra or Lefkada.

Dysdera corfuensis Deeleman-Reinhold et Deeleman, 1988

MATERIAL. Kerkyra: $10^{7} 19$, Kerasia beach, Agios Stephanos, under stones in olive grove, 29.05.1999. Det. C. DeelemanReinhold.

DISTRIBUTION. A species apparently endemic to Kerkyra and Lefkada.

Dysdera murphiorum Deeleman-Reinhold et Deeleman, 1988

MATERIAL. KerkyRa: 6 우, 2 km from Agios Stephanos, under stones in olive grove, 31.05.1999. Det. C. Deeleman-Reinhold.

DISTRIBUTION. Only known from Kerkyra and from Albania.

Harpactea nausicaae Brignoli, 1976

MATERIAL. Kerkyra: $1 \sigma^{7} 1$, house nr. Agios Stephanos, under stones, 3.06.1999. Det. C. Deeleman-Reinhold.

DISTRIBUTION. A species endemic to the Ionian islands of Greece.

Harpactea sp.

MATERIAL. KeRKYRA: 1 ㅇ, Agios Stephanos, under stones in olive grove, 1.06.1999; 1 ㅇ, Behind Kerasia beach, nr. Agios Stephanos, under stones in stream valley, 6.06.1999. — LefKADA: 1 + , W of Mikros Ghialos, among stones in phrygana, 28.05.1993.

COMMENTS. These are not females of $H$. nausicaae, the only other species of the genus reorded from Kerkyra. Until males are collected, it is unwise to assign them to a new species, given the difficulties of reliably distinguishing female Harpactea species.

\section{Family GNAPHOSIDAE} 1874)

Berlandina corcyraea (O. Pickard-Cambridge,

MATERIAL. Kerkyra: 1 , between Erivia and Lafkion, in phrygana, 4.06.1999. - LEFKADA: $1 \sigma^{7}$, W of Mikros Ghialos, under stones in olive grove, 23.05.1993; 1 , Mikros Ghialos, on rocks behind fishing port, 1.06.1995.

DISTRIBUTION. A species previously endemic to Kerkyra. These are the first records from Lefkada.

Drassodes lapidosus (Walckenaer, 1802)

MATERIAL. KerkyRa: 1 , behind Kerasia beach, Agios Stephanos, under stones in stream valley, 6.06.1999; 2 OP, house nr. Agios Stephanos, under stones, 3.06.1999. — LefKadA: $10^{7} 1$, W of Mikros Ghialos, under stones by edge of path, 22.05.1995.

DISTRIBUTION. Throughout the Palaearctic and an abundant species everywhere in Greece.

Drassyllus praeficus (L. Koch, 1866)

MATERIAL. Kerkyra: $1 \sigma^{2}$, house nr. Agios Stephanos, under stones, 3.06.1999; 1 ㅇ. Mt. Pantokrator, under stones in phrygana, 29.05 .1999 . 
DISTRIBUTION. Throughout Europe to central Asia. Common and widespread in Greece. New to Kerkyra.

Drassyllus pumilus (C.L. Koch, 1839)

MATERIAL. KerKyra: $1 \sigma^{\top}$, house nr. Agios Stephanos, under stones, 3.06.1999.

DISTRIBUTION. From central and eastern Europe to central Asia. In Greece there is only one previous record from Rhodes which requires confirmation. New to Kerkyra.

Drassyllus pusillus (C.L. Koch, 1833)

MATERIAL. Kerkyra: $1+$, nr. Agios Stephanos, under stones in old olive grove, 1.06.2000.

DISTRIBUTION. Throughout the Palaearctic but with relatively few records from Attica, Macedonia and Thrace on mainland Greece. New to Kerkyra.

Micaria coarctata (Lucas, 1846)

MATERIAL. KeRKYra: $10^{\top}$, Agni, under stones in olive grove. 2.06.2000

DISTRIBUTION. From the Mediterranean to central Asia. In Greece widespread on Crete but rarely recorded elsewhere.

Nomisia excerpta (O. Pickard-Cambridge, 1872)

MATERIAL. KeRKYRA: 1 , beach S of Avlaki, under stones in short turf, 3.06.2000; 2 우, Agni, in olive grove, under stones. 2.06.2000. - LefKADA: 3 O $^{7} \sigma^{7} 2$ 90 , W of Mikros Ghialos, under stones in olive grove, 23.05.1993; $2 \sigma^{7} \sigma^{7} 2$ PO, beach at Agios Akitas, in marram grass, 27.05.1995; 3 오, Poros, under stones in phrygana, 24.05.1995.

DISTRIBUTION. Tunisia, Israel and Crete. Widespread on Crete and recorded on Chios. New to the Ionian islands.

Nomisia exornata (C.L. Koch, 1839)

MATERIAL. Kerkyra: $1 \sigma^{7}$, Kerasia beach nr. Agios Stephanos, in olive grove, 28.05.2000; $1 \mathrm{O}^{7}$, path from Kerasia beach to Kalami, in phrygana, 26.05.1999; $1 \sigma^{7} 2$ 우, Agios Stephanos, under stones in olive grove, 1.06.1999.

DISTRIBUTION. From the Mediterranean to central Asia. A widespread and common species in Greece.

Nomisia ripariensis (O. Pickard-Cambridge, 1872)

MATERIAL. KeRKYRA: 3 오, house at Kerasia beach, on terrace, 27.05.1999; 5 O $^{7} 0^{7} 7$ 우, Kerasia beach, Agios Stephanos, under stones in olive grove, 25.05-6.06.1999; $1 \sigma^{\prime \prime} 1$, behind Kerasia beach, nr. Agios Stephanos, under stones in stream valley 6.06.1999; $1 \mathrm{O}^{2}$, house near Agios Stephanos, under stones, 3.06.1999.

DISTRIBUTION. Greece to Azerbaijan. As with the previous species, widespread in Greece where the two often occur together. New to Kerkyra.

Scotophaeus scutulatus (L. Koch, 1866)

MATERIAL. LEFKADA: 1 9 , E of Mikros Ghialos, under stones on track, 3.06.1995.

DISTRIBUTION. Europe to central Asia. Widespread in Greece but new to Lefkada.

Trachyzelotes adriaticus (Caporiacco, 1951)

MATERIAL. KeRKYRA: $50^{7} 0^{7} 2$ OO, house nr. Agios Stephanos, under stones, 3.06.1999; 2 우, path from Kerasia beach to
Kalami, under stones in phrygana, 26.05.1999; $10^{7}$, Kerasia beach, Agios Stephanos, under stones below Eucalyptus, 6.06.1999; $1 \mathrm{O}^{\text {?', }}$ same locality, in olive grove, 28.05.2000; $1 \sigma^{7}$, Agni, in olive grove, under stones, 2.06.2000.

DISTRIBUTION. Italy, Crete, the Balkans and China. In Greece recorded from the Ionian islands and Crete.

Trachyzelotes pedestris (C.L. Koch, 1837)

MATERIAL. Kerkyra: 1 , $2 \mathrm{~km}$ from Agios Stephanos, in olive grove, 30.05.1999; 1 ㅇ, Kerasia beach, nr. Agios Stephanos, in olive grove, 28.05.1999; $2 O^{7} \sigma^{7} 1 \%$, house at Kerasia beach, under stones, 27.05.1999. - LEFKADA: 3 우, Mikros Ghialos, grassy glade in olive grove, 23.05.1995; 1 , , valley near Mikros Ghialos, in grass by stream, 3.06.1995.

DISTRIBUTION. From Europe to Azerbaijan. In Greece scattered records across the country but absent from Crete. New to the Ionian islands.

Zelotes balcanicus Deltshev, 2006

MATERIAL. LeFKADA: 2 우, valley behind Mikros Ghialos, under stones, 26.05.1995; 1 , , W of Mikros Ghialos, under stones in olive grove, 25.05.1995.

DISTRIBUTION. Bulgaria, Romania, Greece, Macedonia and Israel.

Zelotes cingarus (O. Pickard-Cambridge, 1874)

MATERIAL. Kerkyra: 5 ㅇ, Kerasia beach, Agios Stephanos, under stones below Eucalyptus and under stones in stream valley, 6.06.1999; 1 \% Agni, in olive grove, under stones 2.06.2000.

DISTRIBUTION. Bulgaria, Greece, Turkey, Tajikistan. Widespread in Greece and often abundant.

Zelotes metellus (Roewer, 1928)

MATERIAL. LEFKADA: $20^{7} \mathrm{O}^{7}, \mathrm{~W}$ of Mikros Ghialos, under stones in phrygana, 28.05.1995.

DISTRIBUTION. From Greece to Iran and Israel. Recorded in Greece from Karpathos, Lesbos, Chios and Crete. New to Lefkada.

Zelotes subterraneus (C.L. Koch, 1833)

MATERIAL. LEFKADA: 7 OP, W of Mikros Ghialos, under stones by edge of path and in phrygana, 22-28.05.1995; 2 우, valley behind Mikros Ghialos, under stones, 22.05.1995.

DISTRIBUTION. Throughout the Palaearctic from Europe to China. Widespread and common in Greece but new to Lefkada.

Zelotes tenuis (L. Koch, 1866)

MATERIAL. KeRKYra: $20^{7} 0^{7}$, Kerasia beach, nr. Agios Stephanos, in olive grove, 28.05.2000; $1 \mathrm{O}^{7}$, same locality, under stones below Eucalyptus, 6.06.1999; $3 \sigma^{7} \sigma^{7}$, house nr. Agios Stephanos, under stones, 3.06.1999.

DISTRIBUTION. From the Mediterranean to Ukraine. Widespread in Greece but new to Kerkyra.

Family HAHNIIDAE

Hahnia pusilla C.L. Koch, 1841

MATERIAL. LEFKADA: 1 +, W of Mikros Ghialos, under stones, 22.05.1995.

DISTRIBUTION. From Europe to Russia. In Greece only previously recorded from Crete and new to Lefkada. 


\section{Family LINYPHIIDAE}

Agyneta fuscipalpa (C.L. Koch, 1836) ?

MATERIAL. LEFKADA: 19 , Mikros Ghialos, in grassy glade in old olive grove, 25.05.1993; 1 , Nidri, under rocks below waterfall, 26.05.1993.

DISTRIBUTION. From Europe to Russia and Mongolia. In Greece previously recorded from Attika and Crete. New to Lefkada.

Agyneta mollis (O. Pickard-Cambridge, 1871)

MATERIAL. LEFKADA: 1 , nr. Nidri, in thick grass in meadow, 2.06.1993. Det. R. Bosmans.

DISTRIBUTION. A western Palaearctic species recorded throughout most of Europe and introduced to China. This is the first record for Greece.

Agyneta ressli (Wunderlich, 1973)

MATERIAL. Kerkyra: $10^{7}$, Kerasia beach, nr. Agios Stephanos, on beach under stones, 6.06.1999; 1 + , Agios Stephanos, on wall of house, 3.06.1999. Det. R. Bosmans.

DISTRIBUTION. Germany, Austria, Switzerland, Greece. New to Kerkyra.

Cresmatoneta mutinensis (Canestrini, 1868)

MATERIAL. Kerkyra: $10^{7}$, Kerasia beach, nr. Agios Stephanos, under stones, 6.06.1999. - LefKada: 1 \%, Mikros Ghialos, in grassy glade in old olive grove, 25.05.1993.

DISTRIBUTION. A Palaearctic species distributed from the Mediterranean to Korea and Japan. In Greece previously reported from three localities on the mainland, Lesbos and Chios. New to Lefkada. 1872)

Diplocephalus graecus (O. Pickard-Cambridge,

MATERIAL. LEFKADA: $1 \sigma^{7}$, Mikros Ghialos, in grassy glade in old olive grove, 25.05.1993. Det. R. Bosmans.

DISTRIBUTION. A Mediterranean species known from Portugal, France, Italy, Romania, Bulgaria and Greece which has recently spread northwards to Belgium, northern France and Britain. The type locality is Kerkyra and it is also recorded from Lesbos. New to Lefkada.

Diplocephalus sp.n.?

MATERIAL. LEFKADA: $2 \sigma^{\top} \sigma^{\top} 1$, , Nidri, under rocks below waterfall, 26.05.1993. Det. R. Bosmans.

COMMENTS. The cephalic lobe and male palpus of these specimens are unlike those of any previously described Diplocephalus species from the Mediterranean region.

Erigone dentipalpis (Wider, 1834)

MATERIAL. LEFKADA: 19 , Porto Katziki, in shrubs at top of cliff, 31.05.1993.

DISTRIBUTION. From Europe to central Russia and introduced in N \& S America as well as Australia and New Zealand. Widespread and common in Greece but new to Lefkada.

Erigonoplus simplex Millidge, 1979

MATERIAL. LEFKADA: $60^{7} 0^{7} 6$ Oㅇ, Mikros Ghialos, in grass by stream valley and in grassy glade in old olive grove, 25.05-
3.06.1993; 1 ․, Nidri, under rocks below waterfall, 26.05.1993. Det. R. Bosmans.

DISTRIBUTION. France, Italy and Greece. The only previous records in Greece are from Kerkyra [Lecigne, 2014].

Frontinellina frutetorum (C.L. Koch, 1834)

MATERIAL. LefKada: 2 o $^{7} 9$ oㅇ, W of Mikros Ghialos, in long grass in abandoned olive grove, beaten from shrubs and among stones in maquis, 23-28.05.1993; $1 \sigma^{7}$, Nidri, under rocks below waterfall, 26.05.1993; 1 , , valley nr. Mikros Ghialos, in grass and herbs, 29.05.1995.

DISTRIBUTION. Throughout the Palaearctic as far East as SW Siberia. Probably the commonest and most widespread linyphiid in Greece and the Mediterranean region as a whole.

Gongylidium rufipes (Linnaeus, 1758)

MATERIAL. LefKADA: $1{ }^{2}$, Porto Katziki, in shrubs at top of cliff, 31.05.1993. Det. R. Bosmans.

DISTRIBUTION. A Palaearctic species. There are two previous records from Greece, both from wetlands in Macedonia [Van Keer et al., 2010; Schröder et al., 2011].

Lepthyphantes magnesiae Brignoli, 1979

MATERIAL. Kerkyra: 1 , Mt. Pantokrator, under stones in phrygana, 29.05.1999. - LeFKADA: 1 ㅇ, nr. Poros, under stones, 24.05.1993; 1 \%, Nidri, under rocks below waterfall, 26.05.1993. Det. R. Bosmans.

DISTRIBUTION. Only known from Greece where it has been previously recorded from Macedonia, Thessaly and the Peloponnese. New to Kerkyra and Lefkada.

Lepthyphantes minutus (Blackwall, 1833)

MATERIAL. Kerkyra: 1 , Kerasia beach, nr. Agios Stephanos, under stones in olive grove, 28.05.1999. Det. R. Bosmans.

DISTRIBUTION. A Palaearctic species recorded from Europe and Russia. In Greece there is only one previous record from Attica. New to Kerkyra.

Palliduphantes byzantinus (Fage, 1931)

MATERIAL. LeFKADA: $70^{\top} 0^{\top} 13$ $1+$, Mikros Ghialos, in grassy glade in old olive grove, 25.05.1993; 2 ऽ $^{\top} \sigma^{7} 9$ 우, Lagrada, nr. Nidri, in grassy meadow, 2.06.1993. Det. R. Bosmans.

DISTRIBUTION. Recorded from Romania, Bulgaria, Macedonia, Greece and Turkey. Quite widespread in Greece.

Palliduphantes corfuensis Wunderlich, 1995

MATERIAL. Kerkyra: $10^{7}$, Kerasia beach, nr. Agios Stephanos, under stones, 6.06.1999; 1 ․ Agios Stephanos, under stones in olive grove, 28.05.1999. Det. R. Bosmans.

DISTRIBUTION. Only known from Kerkyra.

Tenuiphantes herbicola (Simon, 1884)

MATERIAL. KeRKyra: $30^{7} \sigma^{\top} 14$ 우, Kerasia beach, nr. Agios Stephanos, under stones in olive grove and in stream bed, 25.056.06.1999; $10^{7} 2$ 우, Agios Stephanos, under stones in olive grove and on wall of house, 28.05-3.06.1999; $1 \sigma^{7}$, same locality and habitat, 31.05.2000; $2 O^{\top} 0^{\top} 2$ + $+9,2 \mathrm{~km} \mathrm{~W}$ of Agios Stephanos, in olive grove, 30.05.1999. - LEFKADA: 1 , Nidri, under rocks below waterfall, 26.05.1993; $1 \mathrm{O}^{\top}$, Behind Mikros Ghialos, in grass by stream valley, 3.06.1993. Det. R. Bosmans. 
DISTRIBUTION. Spain, France, Italy and Croatia. These are the first records from Greece.

Tenuiphantes tenuis (Blackwall, 1852)

MATERIAL. LEFKADA: 1 , nr. Poros, on shrubs in phrygana, 24.05.1993; $2 \bigcirc^{7} \sigma^{7} 3$ 우, Mikros Ghialos, in grassy glade in old olive grove, 25.05.1993; $1 \sigma^{7} 5$ 우, Lagrada, nr. Nidri, in grassy meadow, 2.06.1993.

DISTRIBUTION. Throughout the Palaearctic and widespread in Greece.

Trichoncus sordidus Simon, 1884

MATERIAL. Kerkyra: 2 ㅇ, between Agios Stephanos and Kouloura, on rocks on shore, 6.06.1999. Det. R. Bosmans.

DISTRIBUTION. France, Germany, Slovakia, Italy, Slovenia and Croatia. This is the first record from Greece.

\section{Family MIMETIDAE}

Mimetus laevigatus (Keyserling, 1863)

MATERIAL. KerKyra: $1 \sigma^{7}$, Agios Stephanos, under stones in olive grove, 1.06.1999. - LEFKADA: $1 \mathrm{O}^{7}, \mathrm{~W}$ of Mikros Ghialos, beaten from shrubs, 28.05.1995; 1 +, valley nr. Mikros Ghialos, in grass and herbs, 29.05.1995.

DISTRIBUTION. A species with a Palaearctic distribution, widespread throughout the Mediterranean and very common in Greece. New to Kerkyra and Lefkada.

\section{Family MITURGIDAE}

Cheiracanthium elegans Thorell, 1875

MATERIAL. KerkyRa: $1 \mathrm{O}^{7}$, S of Avlaki, beaten from gian heather, 3.06.2000. - LEFKADA: $2 \sigma^{7} \sigma^{7}$, W of Mikros Ghialos, beaten from shrubs, 28.05.1995.

DISTRIBUTION. Distributed from Europe to central Asia. The only previous record from Greece is from Chios. New to Kerkyra and Lefkada.

Cheiracanthium mildei L. Koch, 1864

MATERIAL. Kerkyra: 1 , Agni, under stones in olive grove, 2.06.2000; 1 \% , between Erivia and Lafkion, in phrygana, 4.06.1999.

DISTRIBUTION. A common and widespread species throughout the Mediterranean area and occurring as far east as central Asia.

Cheiracanthium montanum L. Koch, 1877

MATERIAL. LefKADA: 1 ㅇ, nr. Mikros Ghialos, in house, 2.06.1995.

DISTRIBUTION. The Palaearctic from Europe to eastern Siberia, In Greece only previously recorded from Chios. New to Lefkada.

\section{Family OECOBIIDAE}

Oecobius navus Blackwall, 1859?

MATERIAL. Kerkyra: $1 \sigma^{7}$, Kerasia beach, nr. Agios Stephanos, under stones in stream bed, 6.06.1999.

DISTRIBUTION. Found throughout much of Europe and in Georgia and Azerbaijan. It is quite widespread in Greece although not recorded in Crete.

Uroctea durandi (Latreille, 1809)

MATERIAL. Kerkyra: 1 , Kerasia beach, nr. Agios Stephanos, under stones in olive grove, 25.05.1999.
DISTRIBUTION. Widespread in the Mediterranean but relatively infrequent records from Greece.

\section{Family OXYOPIDAE}

Oxyopes lineatus Latreille, 1806

MATERIAL. Kerkyra: $10^{\top} 1$ 엉, Agios Stephanos, under stones in olive grove, 28.05.1999. - LeFKADA: $1 \sigma^{7} 1$ + , W of Mikros Ghialos, beaten from shrubs, 25.05.1993; $1 \sigma^{7}$, nr. Poros, beaten from shrubs in phrygana, 5.06.1995.

DISTRIBUTION. A widespread species in the Mediterranean which extends eastwards to central Asia.

\section{Family PALPIMANIDAE}

Anagraphis cf. pallida (Hadjissarantos, 1940)

MATERIAL. Kerkyra: 1 \%, Kerasia beach, Agios Stephanos, under stones below Eucalyptus, 6.06.1999.

COMMENTS. The epigyne shows some small differences to the figure in Chatzaki et al. [2002], but is considered correctly placed here.

DISTRIBUTION. Recorded from the eastern Mediterranean and South Africa. All previous records from Greece are from Crete.

\section{Palpimanus gibbulus Dufour, 1820}

MATERIAL. KeRKYRA: $1 \sigma^{\top} 2$ +9 , between Erivia and Lafkion, in phrygana, 4.06.1999; 2 우, Mt. Pantokrator, under stones in phrygana, 29.05.1999. - LEFKADA: 1 으. E of Mikros Ghialos, under stones, 3.06.1995; 2 우, W of Mikros Ghialos, under stones in olive grove, 23.05.1993; $1 \bigcirc^{7} 19$, same locality, under stones in maquis, 28.05.1995; 2 우, valley W of Mikros Ghialos, under stones, 26.05.1995.

DISTRIBUTION. A Mediterranean species which is found eastwards to central Asia. Common and very widespread in Greece. New to Kerkyra.

\section{Family PHILODROMIDAE}

Philodromus lunatus Muster et Thaler, 2004

MATERIAL. KeRKYRA: 3 ㅇ, $\mathrm{S}$ of Avlaki, beaten from giant heather, 3.06.2000. - LEFKADA: $1 \sigma^{7}$, Mikros Ghialos, in grassy glade in old olive grove, 25.05.1995; $5 \mathrm{O}^{7} \mathrm{O}^{7}$. W of Mikros Ghialos, beaten from shrubs, 28.05.1995; $2 \mathrm{O}^{7} \mathrm{O}^{\top} 4$ 우, nr. Poros, on shrubs in phrygana, 24.05.1993; $20^{7} \sigma^{7} 1$, top of cliffs at Porto Katsiki, on shrubs in phrygana, 31.05.1993.

DISTRIBUTION. Recorded from Croatia, Greece and Turkey. It is a common species in Greece but new to Lefkada.

Philodromus pulchellus Lucas, 1846

MATERIAL. Kerkyra: 1 , Kerasia beach, Agios Stephanos, under stones in olive grove, 29.05.1999; 1 , Avlaki, short turf on beach, 3.06.2000. - LefKADA: 1 , W of Mikros Ghialos, under stones in olive grove, 23.05.1993.

DISTRIBUTION. $P$. pulchellus has a circum-Mediterranean distribution and is very widespread in Greece. New to Kerkyra and Lefkada.

Thanatus vulgaris Simon, 1870

MATERIAL. Kerkyra: 3 우, Avlaki, short turf on beach, 3.06.2000; 1 O $^{\top} 2$ 우, house nr. Agios Stephanos, under stones, 3.06.1999; $1 \sigma^{7}$, between Agios Stephanos and Koulouri, on rocks in cove. 6.06.1999. 
DISTRIBUTION. An Holarctic species which is very common and widespread in Greece. New to Kerkyra.

Tibellus macellus Simon, 1875

MATERIAL. KeRKYRA: $2 O^{7} O^{7} 2$ ++ , Kerasia beach, nr. Agios Stephanos, under stones in olive grove, 25.05.1999; $1 \mathrm{O}^{2}, 2 \mathrm{~km} \mathrm{~W}$ of Agios Stephanos, in olive grove, 30.05.1999.

DISTRIBUTION. Distributed from southern Europe to central Asia, this species is widespread in the Mediterranean region and a common spider in Greece. New to Kerkyra.

\section{Family PRODIDOMIDAE}

Prodidomus amaranthinus (Lucas, 1846)

MATERIAL. LEFKADA: $1+$, W of Mikros Ghialos, under stones in olive grove, 23.05.1993.

DISTRIBUTION. Mediterranean. In Greece there are a few records from Attica and from Chios. New to Lefkada.

\section{Family SALTICIDAE}

Chalcoscirtus infimus (Simon, 1868)

MATERIAL. KerKyra: $1 \sigma^{7} 1 \%$, path from Kerasia beach to Kalami, under stones in phrygana, 26.05.1999; 1 , house at Kerasia beach, on terrace, 27.05.1999.

DISTRIBUTION. From southern Europe, extending eastwards to central Asia. Widespread throughout Greece.

Cyrba algerina (Lucas, 1846)

MATERIAL. KeRKYRA: 3 O $^{\top} 0^{\top} 2$ + + , Kerasia beach, Agios Stephanos, on and under stones in olive grove, 29.05-6.06.1999; $2 \sigma^{7} \sigma^{7} 4$ 우, Agios Stephanos, under stones in olive grove, 2.06.2000; $50^{7} \sigma^{7}$, path from Kerasia beach to Kalami, under stones in phrygana, 26.05.1999; $2 \sigma^{7} \sigma^{7}$, above Achladia, under stones in hillside phrygana, 2.06.2000. - LEFKADA: $3 \sigma^{7} \sigma^{7} 2$ 우, valley behind Mikros Ghialos, on rocks in grass, 1.06.1995; $3 \mathrm{O}^{7} \mathrm{O}^{\top}, \mathrm{W}$ of Mikros Ghialos, under stones in olive grove, 23.05.1993; $4 \sigma^{7} \sigma^{7} 1$, same locality, under stones in maquis, 28.05.1995; $1 \mathrm{O}^{7}$, valley nr. Mikros Ghialos, on rock face, 29.05.1995; $1 \mathrm{O}^{7} 2$ 우, E of Mikros Ghialos, under stones, $3.06 .1995 ; 1 \mathrm{O}^{7}$, top of cliffs at Porto Katsiki, on shrubs in phrygana, 31.05.1993; $1 \mathrm{O}^{7}$, nr. Nidri, in thick grass in meadow, 2.06.1993.

DISTRIBUTION. A widespread and abundant species throughout the Mediterranean, extending eastwards to central Asia.

Dendryphantes rudis (Sundevall, 1833)

MATERIAL. LEFKADA: 1 , valley W of Mikros Ghialos, beaten from shrubs, 25.05.1993.

DISTRIBUTION. A Palaearctic species but apparently rare in Greece with only one previous record from Syros. New to Lefkada.

\section{Euophrys gambosa (Simon, 1868)}

MATERIAL. KeRKYRA: 19 , path from Kerasia beach to Kalami, under stones in phrygana, 26.05.1999; 1 , Mt. Pantocrator, in phrygana, 29.05.1999; $1 \mathrm{O}^{7} 2$ 우, Agios Stephanos, under stones in olive grove, 1.06.2000; 1 + , Avlaki, short turf on beach, 3.06.2000.

DISTRIBUTION. A western Palaearctic species recorded from Spain, France, Italy and Greece. Previously recorded from Attica and the Dodecanese. In Greece, these are the first records from Kerkyra.
Euophrys herbigrada (Simon, 1871)

MATERIAL. Kerkyra: 1 , Kerasia beach, Agios Stephanos, under stones in olive grove, 29.05.1999.

DISTRIBUTION. A western Palaearctic species recorded from western but not from eastern Europe. There are a few scattered records from Greece where it does not appear to be very common.

\section{Euophrys rufibarbis (Simon, 1868)}

MATERIAL. KeRKYRA: $2 \sigma^{7} O^{7}$, on wall of house at Kerasia beach, 27.05.1999; $2 \mathrm{O}^{7} \sigma^{7}, 2 \mathrm{~km}$ W of Agios Stephanos, in olive grove, 31.05.1999; 1 o $^{\top} 1$ \% , Kerasia beach, Agios Stephanos, under stones below Eucalyptus, 6.06.1999. — LEFKADA: $1 \mathrm{O}^{7} 3$ 우, valley behind Mikros Ghialos, on rocks in grass, 1-3.06.1995; 1 $\mathrm{O}^{7}$, Lagkada, nr. Nidri, in tall meadow grass, 2.06.1995; $1 \mathrm{O}^{7} 1$, W of Mikros Ghialos, under stones, 22.05.1995; $2 \mathrm{O}^{7} \mathrm{O}^{7}$, Mikros Ghialos, grassy glade in olive grove, 23.05.1993; 1 $9, \mathrm{~W}$ of Mikros Ghialos, under stones in olive grove, 23.05.1993; $1 \mathrm{O}^{7}$, same locality, under stones in maquis. 28.05.1995. Det. H. Metzner.

DISTRIBUTION. Recorded throughout the Palaearctic from Europe to China. A widespread species in Greece.

\section{Evarcha jucunda (Lucas, 1846)}

MATERIAL. Kerkyra: $15 \sigma^{\top} \sigma^{\top} 2$ 90 , Kerasia beach nr. Agios Stephanos, under stones in olive grove, 25.05-6.06.1999; $2 \sigma^{7} \sigma^{7} 2$ +0 , path from Kerasia beach to Kalami, under stones in phrygana,. 26.05.1999; $4 \sigma^{\top} \sigma^{7}$, on terrace and walls of house at Kerasia beach, 27.05-3.06.1999; 1 ऽ 2 오, Kerasia beach, nr. Agios Stephanos, under stones in olive grove, 29.05.1999; $3 \sigma^{\top} \sigma^{\top} 2$ 우, same locality and habitat, 1.06.2000; $1 \sigma^{7}$, between Erivia and Lafkion, in phrygana, 4.06.1999; $1 \sigma^{7}$, between Agios Stephanos and Koulouri, on rocks in cove, 6.06.1999; $1 \sigma^{7} 1 \%$, S of Avlaki, beaten from giant heather, 3.06.2000; $1 \sigma^{7}$, Avlaki, in short turf on beach, 3.06.2000. - LeFKADA: $4 \sigma^{\top} \sigma^{\top} 2$ O+口, valley nr. Mikros Ghialos, on rocks in grass, 29.05-3.06.1995; $1 \sigma^{7}$, W of Mikros Ghialos, under stones in olive grove, 23.05.1993; $1 \sigma^{\top}$, beach at Agios Akitas, in marram grass, 27.05.1995; $1 \sigma^{7}$, W of Mikros Ghialos, under stones in maquis, 28.05.1995; 3 ठำ 1 \% , Mikros Ghialos, on house walls. 28.05.1995.

DISTRIBUTION. A very widespread Mediterranean species which is abundant throughout Greece. New to Lefkada.

Habrocestum graecum Dalmas, 1920

MATERIAL. Kerkyra: 3 O $^{7} \sigma^{7}$, Agios Stephanos, house at Kerasia beach, on terrace and walls, 27.05-3.06.1999; 5 O $^{7} 0^{7} 3$ 우, Kerasia beach, Agios Stephanos, under stones in olive grove, 28.051.06.1999; 5 O $^{7} \sigma^{7} 2$ 우, samel locality and habitat, 31.05.2000. LEFKADA: 3 O $^{\top} \mathrm{O}^{\top} 1$ \% , valley nr. Mikros Ghialos, on rocks in grass, 29.05-1.06.1995; $5 \mathrm{O}^{7} \mathrm{O}^{7}, \mathrm{~W}$ of Mikros Ghialos, under stones in olive grove, 23.05.1993; $3 \mathrm{O}^{7} \sigma^{7}$, same locality, under stones in maquis, 28.05.1995.

DISTRIBUTION. A species endemic to Greece where it is widespread but absent from the eastern Aegean and Crete. New to Lefkada.

Heliophanus kochii Simon, 1868

MATERIAL. Kerkyra: 1 , between Agios Stephanos and Koulouri, on rocks in cove, 6.06.1999.

DISTRIBUTION. A species distributed from the Mediterranean to Asia Minor. Widespread and extremely common in Greece.

Heliophanus lineiventris Simon, 1868

MATERIAL. Kerkyra: $1 \sigma^{7}$, Mt. Pantocrator, on stone in phrygana, 29.05.1999; $1 \sigma^{\top}$, between Erivia and Lafkion, in phryg- 
ana, 4.06.1999; 1 ○ 2 우, Kerasia beach, nr. Agios Stephanos, on stones by dry stream, 6.06.1999. — LEFKADA: $1 \sigma^{7}$, Nidri, on rocks in gorge, 26.05.1995.

DISTRIBUTION. A Palaearctic species which is very widespread in Greece. New to Lefkada.

Heliophanus melinus L. Koch, 1867

MATERIAL. KERKYRA: 2 o+, path from Kerasia beach to Kalami, under stones in phrygana, 26.05.1999; 1 o', Kerasia beach, nr. Agios Stephanos, under stones in olive grove, 29.05.1999; 1 \%, Mt. Pantocrator, in phrygana, 29.05.1999; 2 +9 , between Erivia and Lafkion, under stones in phrygana, 4.06.1999. - LefKAdA: $1 \sigma^{7} 3$ OQ⿻, W of Mikros Ghialos, under stones in maquis, 22-28.05.1995; 1 ○ 3 우, same locality, under stones in olive grove, 23.05.1993; 2 o+ , valley nr. Mikros Ghialos, on plants, 29.05.1995; 2 우, E of Mikros Ghialos, under stones, 3.06.1995; 3 우, top of cliffs at Porto Katsiki, on shrubs in phrygana, 31.05.1993.

DISTRIBUTION. Throughout Europe but particularly common in the Mediterranean and an abundant and widespread species in Greece. New to Lefkada.

Heliophanus tribulosus Simon, 1868

MATERIAL. KERKYRA: $4 \sigma^{\top} \sigma^{7} 2$ 90 , house at Kerasia beach, on terrace and walls, 27.05.1999. - LEFKADA: $1 \sigma^{\top} 1$ ㅇ, W of Mikros Ghialos, under stones in maquis, 22-28.05.1995; $2 \sigma^{7} \sigma^{7}$, same locality, under stones in olive grove, 23.05.1993; 1 \%, $\mathrm{nr}$. Poros, under stones, 24.05.1995; 1 \%, E of Mikros Ghialos, under stones, 3.06.1995.

DISTRIBUTION. Distributed from western Europe to Kazakhstan and very widespread in Greece.

Leptorchestes berolinensis (C.L. Koch, 1846)

MATERIAL. LEFKADA: $2 \sigma^{7} \sigma^{7}$, valley nr. Mikros Ghialos, on rock face, 29.05.1995. Det. D. Logunov.

DISTRIBUTION. A western Palaearctic species recorded from Europe to Turkmenistan. There are a few scattered records in Greece from Attica, the Peloponnese and the Ionian islands.

Leptorchestes mutilloides (Lucas, 1846)

MATERIAL. KeRKYRA: $1 \sigma^{7}$, between Erivia and Lafkion, under stones in phrygana, 4.06.1999; $1 \sigma^{7}$, Avlaki, short turf on beach, 3.06.2000.

DISTRIBUTION. A Mediterranean species ocurring from Spain to Turkey. In Greece, only scatterend records from Attica, the Dodecanese and Pelopennese. New to Kerkyra.

Macaroeris flavicomus (Simon, 1884)

MATERIAL. KeRKYRA: 1 , on wall of house at Kerasia beach, 3.06.1999.

DISTRIBUTION. Known from Greece, Turkey and the Ukraine. Scattered records in Greece from Macedonia, Attica, the Cyclades and the Pelopennese. New to Kerkyra.

Macaroeris nidicolens (Walckenaer, 1802)

MATERIAL. LEFKADA: 1 , W of Mikros Ghialos, under stones in olive grove, 23.05.1993; $1 \sigma^{7} 1$, same locality, under stones in maquis, 28.05.1995.

DISTRIBUTION. From Europe to central Asia. A widespread and common species in Greece but new to Lefkada.
Menemerus semilimbatus (Hahn, 1829)

MATERIAL. KeRKYRA: $1 \sigma^{7}$, path from Kerasia beach to Kala$\mathrm{mi}$, in phrygana, 26.05.1999; $3 \mathrm{O}^{7} \mathrm{O}^{7} 1$ 을 house at Kerasia beach, on terrace and walls, 28.05-3.06.1999; $5 \sigma^{\top} \sigma^{7} 1$, between Agios

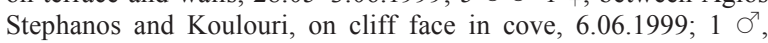
Agios Stephanos, under stones in olive grove, 31.05.2000. - LEFKADA: $2 O^{\top} O^{7} 2$ qO, valley behind Mikros Ghialos, on rocks in grass, 26.05-1.06.1995; 4 O $^{\top} \mathrm{O}^{\top} 3$ 우, valley nr. Mikros Ghialos, on rock face and in grass, 29.05-3.06.1995.

DISTRIBUTION. From Spain to Azerbaijan and introduced to the New World. Widespread and abundant in Greece. New to Lefkada.

Philaeus chrysops (Poda, 1761)

MATERIAL. KeRKYRA: $20^{7} \sigma^{7} 1 \bigcirc$, house at Kerasia beach, on stone wall, 27.05-3.06.1999; $2 \sigma^{7} \sigma^{7}$, Mt. Pantocrator, on stone in phrygana, 29.05.1999. - LeFKADA: $2 \sigma^{7} \sigma^{7} 1$ \% , valley nr. Mikros Ghialos, under stones in long grass, 29.05-1.06.1995; $1 \mathrm{O}^{7} 2$ 웅, W of Mikros Ghialos, under stones, 22-28.05.1995; $1 \mathrm{O}^{7}$, same locality, under stones in olive grove, 23.05.1993; $1 \mathrm{O}^{7}$, beach at Agios Akitas, in marram grass, 27.05.1995.

DISTRIBUTION. Throughout the Palaearctic and widespread in Greece as elsewhere in the Mediterranean.

Phlegra fasciata (Hahn, 1826)

MATERIAL. Kerkyra: $1 \sigma^{7}$, Kerasia beach nr. Agios Stephanos, under stones in olive grove, 28.05.1999; $1 \sigma^{7}$, Mt. Pantocrator, on stone in phrygana, 29.05.1999; $1 \sigma^{\top}$, Avlaki, short turf on beach, 3.06.2000; $1 \sigma^{7}$, between Erivia and Lafkion, under stones in phrygana, 4.06.1999. - LeFKADA: $1 \sigma^{7} 1$ ㅇ, valley behind Mikros Ghialos, on rocks in grass, 1.06.1995; $1 \mathrm{O}^{7}$, W of Mikros Ghialos, under stones, 22.05.1995.

DISTRIBUTION. Palaearctic. Widespread and common in Greece. New to Lefkada.

Pseudeuophrys obsoleta (Simon, 1868)

MATERIAL. Kerkyra: $1 \sigma^{7}$, Kerasia beach, Agios Stephanos, under stones in olive grove, 28.05.1999; $2 \sigma^{7} \sigma^{7} 2$ 우, between Erivia and Lafkion, under stones in phrygana, 4.06.1999.

DISTRIBUTION. Throughout the Palaearctic from France to China. Widespread and common in Greece.

Pseudeuophrys vafra (Blackwall, 1867)

MATERIAL. KERKYRA: $20^{7} \sigma^{7} 2$ 우, house at Kerasia beach, on terrace and walls, 28.05.1999; $1 \mathrm{O}^{\top}, 2 \mathrm{~km} \mathrm{~W}$ of Agios Stephanos, in olive grove, 31.05.1999; $1 \mathrm{O}^{\top} 2$ 우, Kerasia beach, nr. Agios Stephanos, on and undert stones below Eucalyptus, 6.06.1999; $1 \sigma^{7}$ 3 오, Agios Stephanos, under stones in olive grove, 31.05.2000.

DISTRIBUTION. From the Mediterranean to central European Russia. A few scattered records in Greece and new to Kerkyra.

Pseudicius picaceus (Simon, 1868)

MATERIAL. LeFKADA: $3 \bigcirc^{7} \sigma^{7}$, valley nr. Mikros Ghialos, on rocks in grass, 1-3.06.1995; $1 \sigma^{7}$, W of Mikros Ghialos, under stones in olive grove, 23.05.1993; 2 우, E of Mikros Ghialos, under stones, 3.06.1995; $20^{7} \sigma^{7}$, Mikros Ghialos, on house walls, 4.06.1995.

DISTRIBUTION. From Italy to Azerbaijan. A widespread and common species in Greece but new to Lefkada.

Saitis graecus Kulczyński, 1904

MATERIAL. KeRKYRA: $3 \mathrm{O}^{7} \mathrm{O}^{7} 7$ 우, Kerasia beach, nr. Agios Stephanos, under stones in olive grove and below Eucalyptus, 25.05-6.06.1999; 1 , , same locality and habitat, 1.06.2000; 1 , 
house at Kerasia beach, on walls, 3.06.1999; 1 + , Agni, under stones in olive grove, 2.06.2000. - LEFKADA: 1 , $\mathrm{W}$ of Mikros Ghialos, under stones in olive grove, 23.05.1993; 1 , valley behind Mikros Ghialos, on rocks in grass, 26.05.1995. Det. H. Metzner.

DISTRIBUTION. Recorded from Greece, Romania and Bulgaria. Scattered records across Greece but absent from the eastern Aegean and Crete. New to Lefkada.

Salticus mandibularis (Simon, 1868)

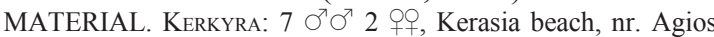
Stephanos, under stones in olive grove, 28.05-6.06.1999; $3 \sigma^{7} \sigma^{7} 1$ +, Agios Stephanos, under stones in olive grove, 31.05.2000; $5 \sigma^{\top} \sigma^{\top}$, on terrace and wall of house at Kerasia beach, 28.05.1999. LEFKADA: $3 \sigma^{7} \sigma^{7}$, Nidri, on rocks in gorge below waterfall, 26.05.1995.

DISTRIBUTION. Recorded from Italy and Greece. There is one previous record from Kerkyra but the only other Greek record is from Dionisos in Attica. New to Lefkada.

Synagales dalmaticus (Keyserling, 1863)

MATERIAL. Kerkyra: $1 \sigma^{7}$, Kerasia beach, nr. Agios Stephanos, under stones in olive grove, 29.05.1999; $2 \sigma^{7} \sigma^{\top}$, Agios Stephanos, under stones in olive grove, 1.06.2000. — LEFKADA: $1 \sigma^{7}$, valley nr. Mikros Ghialos, on stones, 26.05.1995; 2 으, top of cliffs at Porto Katsiki, on shrubs in phrygana, 31.05.1995.

DISTRIBUTION. Mediterranean and as far East as Azerbaijan. Very widespread in Greece but new to Lefkada.

Thyene imperialis (Rossi, 1846)

MATERIAL. LEFKADA: $1 \sigma^{7}$, valley nr. Mikros Ghialos, on rock face, 29.05.1995.

DISTRIBUTION. Through much of the Old World although confined to the Mediterranean in Europe. A widespread species in Greece. New to Lefkada.

\section{Family SCYTODIDAE}

Scytodes thoracica (Latreille, 1802)

MATERIAL. Kerkyra: 1 , Agni, under stones in olive grove, 2.06.2000; 1 , path from Kerasia beach to Kalami, under stones in phrygana, 26.05.1999; 1 9. Mt. Pantokrator, under stones in phrygana, 29.05.1999. - LeFKADA: 2 우, behind Mikros Ghialos, under stones, 29.05.1995; $1 \bigcirc^{\top} 2$ 우, W of Mikros Ghialos, under stones in maquis and in olive grove, 23-28.05.1995.

DISTRIBUTION. A species with a Holarctic distribution. Widespread and abundant throughout Greece.

\section{Family SICARIIDAE}

Loxosceles rufescens (Dufour, 1820)

MATERIAL. LEFKADA: 19 , W of Mikros Ghialos, under stones in maquis, 28.05.1995; $1 \sigma^{7}$, E of Mikros Ghialos, under stones, 3.06.1995; 1 T 2 우, Mikros Ghialos, on house walls, 2.06.1995.

DISTRIBUTION. An almost cosmopolitan species in warmer climates which is widespread and very common in Greece.

\section{Family SPARASSIDAE}

Micrommata ligurina (C.L. Koch, 1845)

MATERIAL. Kerkyra: 1 + Agios Stephanos, under stones in olive grove, 1.06.1999.

DISTRIBUTION. From the Mediterranean to central Asia. Widespread in Greece but new to Kerkyra.
Olios argelasius (Walckenaer, 1805)

MATERIAL. LEFKADA: $1 \bigcirc^{7}$, Mikros Ghialos, on house wall, 31.05.1995.

DISTRIBUTION. A Mediterranean species with scattered records throughout most of Greece except in the North. New to Lefkada.

\section{Family TETRAGNATHIDAE}

Pachygnatha degeeri Sundevall, 1830

MATERIAL. LEFKADA: $90^{7} \sigma^{7} 11$ 우, Nidri, in thick grass in meadow, 2.06.1993.

DISTRIBUTION. Distributed across the Palaearctic from Europe to far eastern Siberia. There are a few scattered records from Greece, mainly from the North. New to Lefkada.

Metellina merianae (Scopoli, 1763)

MATERIAL. Kerkyra: $19,2 \mathrm{~km}$ W of Agios Stephanos, in olive grove, 30.05.1999. - LEFKADA: $1 \sigma^{7} 1$, Nidri, under rocks in gorge, 26.05.1995; $2 \sigma^{7} \sigma^{7}$, Mikros Ghialos, on house walls, 27.05 .1995

DISTRIBUTION. Recorded from Spain to Georgia. Widespread in Greece.

Tetragnatha extensa (Linnaeus, 1758)

MATERIAL. LEFKADA: 1 , behind Mikros Ghialos, in grass, 1.06.1995.

DISTRIBUTION. A Holarctic species which is fairly widespread in Greece but not common.

Tetragnatha montana Simon, 1874

MATERIAL. LEFKADA: $1 \sigma^{\top}$, behind Mikros Ghialos, in grass by stream, 3.06.1995.

DISTRIBUTION. Throughout the Palaearctic. There are only a handful of records from Greece and it is new to Lefkada.

\section{Family THERIDIIDAE}

Achaearanea tepidariorum (C.L. Koch, 1841)

MATERIAL. KerkyRA: 1 , S of Avlaki, beaten from giant heather, 3.06.2000; 1 ㅇ, nr. Agios Stephanos; under stones, old olive grove, 1.06.2000.

DISTRIBUTION. A cosmopolitan species but only previously recorded twice from Greece. New to Kerkyra.

Kochiura aulica (C.L. Koch, 1838)

MATERIAL. LEFKADA: $2 \bigcirc^{7} \sigma^{7}$, Mikros Ghialos, in grass behind fishing port, 1.06.1995.

DISTRIBUTION. Europe to Azerbaijan. Fairly widespread in Greece. New to Lefkada.

Argyrodes argyrodes (Walckenaer, 1841)

MATERIAL. KeRKYrA: $1 \sigma^{7} 1$ $9, \mathrm{~S}$ of Avlaki, beaten from giant heather, 3.06.2000. - LefKADA: $1 \sigma^{7} 1$ \%, Mikros Ghialos, in grass behind fishing port, 1.06.1995.

DISTRIBUTION. A Mediterranean species recorded from Spain to the Ionian islands of Greece. New to Lefkada.

Crustulina scabripes Simon, 1881

MATERIAL. Kerkyra: 1 , Kerasia, nr. Agios Stephanos, in olive grove, 28.05.1999; $1 \mathrm{O}^{\top}, 2 \mathrm{~km}$ from Agios Stephanos, in olive grove, 30.05.1999; $1 \mathrm{O}^{7}, \mathrm{~S}$ of Avlaki, under stones in short turf, 
2.06.1999. - LeFKADA: $1 \sigma^{\top} 1$ + , Mikros Ghialos, in grass behind fishing port, 1.06.1995; $1 \sigma^{\gamma} 2$ 우, E of Mikros Ghialos, under

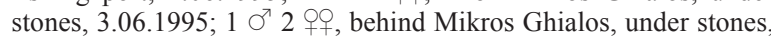
29.05-3.06.1995.

DISTRIBUTION. Largely Mediterranean from Spain to Azerbaijan. Widespread and fairly common in Greece. New to Kerkyra and Lefkada.

\section{Dipoena sp.}

MATERIAL. Kerkyra: 1 , house nr. Agios Stephanos, under stones, 3.06.1999. - LEFKADA: 1 ㅇ, W of Mikros Ghialos, under stones in maquis, 28.05.1995.

COMMENTS. The genus Dipoena is in need of complete revision in the Mediterranean region and females are not always assignable to a known species.

Enoplognatha afrodite Hippa et Oksala, 1983

MATERIAL. LEFKADA: 4 우, behind Mikros Ghialos, in grass, $1.06 .1995 ; 1$, nr. Poros, beaten from shrubs in phrygana, 24.05.1995; 5 우, valley W of Mikros Ghialos, beaten from shrubs and among stones, 25-26.05.1995. Det. B. Knoflach.

DISTRIBUTION. Southern Europe and Turkey. Widespread in Greece.

Enoplognatha macrochelis Levy et Amitai, 1981

MATERIAL. LEFKADA: $1+$, Agios Nikitos, in marram grass on dunes, 27.05.1995. Det. B. Knoflach.

DISTRIBUTION. Greece, Turkey, Cyprus, Israel $\&$ Azerbaijan. Widespread and common in Greece but new to Lefkada.

Enoplognatha penelope Hippa et Oksala, 1982

MATERIAL. Kerkyra: 1 sub $\circ$, Kerasia, nr. Agios Stephanos, in olive grove, 28.05.2000. - LeFKADA: $3 \sigma^{7} \sigma^{7}$, behind Mikros Ghialos, in grass, $1.06 .1995 ; 1 \%$, nr. Poros, beaten from shrubs in phrygana, 24.05.1995. Det. B. Knoflach.

DISTRIBUTION. Recorded from Bulgaria and Greece where it is reasonably common. New to Kerkyra and Lefkada.

Enoplognatha quadripunctata Simon, 1884

MATERIAL. Kerkyra: 2 OO , Kerasia beach, nr. Agios Stephanos, in olive grove, 28.05.2000; 1 \% , nr. Agios Spiridion, under stones in old olive grove, 4.06.2000. - LeFKADA: 1 o, W of Mikros Ghialos, under stones in old olive grove, 23.05.1993; 2 우, nr. Poros, beaten from shrubs in phrygana, 24.05.1995. Det. B. Knoflach.

DISTRIBUTION. Mediterranean to Azerbaijan. A common and widespread species in Greece. New to Lefkada

Episinus truncatus Latreille, 1809

MATERIAL. KeRKYra: 1 , Agni, under stones in olive grove, 2.06.2000. - LefKadA: $4 O^{7} \sigma^{7} 7$ OO , behind Mikros Ghialos, in grass, 3.06.1995; 1 , nr. Poros, beaten from shrubs in phrygana, 24.05.1995; $4 \bigcirc^{7} \sigma^{7} 1$, , Mikros Ghialos, grassy glade beneath olive trees, 20.05.1995.

DISTRIBUTION. Palaearctic from Europe to central Russia. There are scattered records from Greece but new to Kerkyra and Lefkada.

Euryopis sexalbomaculata (Lucas, 1846)

MATERIAL. Kerkyra: $20^{7} O^{7} 2$ 우, Kerasia, nr. Agios Stephanos, in olive grove, 28.05.1999; 1 , behind Kerasia beach, nr. Agios Stephanos, under stones in stream valley, 6.06.1999.
DISTRIBUTION. Recorded from the Ukraine, Bulgaria and Greece. There are only a very few records from the latter country. New to Kerkyra.

Neottiura herbigrada (Simon, 1873)

MATERIAL. LEFKADA: $1 \sigma^{7}$, Mikros Ghialos, grassy glade beneath olive trees, 20.05.1995; 5 우, Mikros Ghialos, grassy glade beneath olive trees, 20.05.1995; 1 , , behind Mikros Ghialos, in grass, 1.06.1995. Det. B. Knoflach.

DISTRIBUTION. Mediterraean, China and Korea. There are scattered records from Greece but new to Lefkada.

Simitidion simile (C.L. Koch, 1836)

MATERIAL. Kerkyra: 1 , behind Kerasia beach, nr. Agios Stephanos, under stones in stream valley, 6.06.1999. — LEFKADA: 1 + , W of Mikros Ghialos, 27.05.1995; 1 , behind Mikros Ghialos, in grass, 3.06.1995; $1+$, nr. Poros, beaten from shrubs in phrygana, 24.05.1995; $1 \mathrm{O}^{7} 1$, , in valley W of Mikros Ghialos, beaten from shrubs, 25.05.1995.

DISTRIBUTION. A Holarctic species widespread in Greece. New to Lefkada.

Steatoda paykulliana (Walckenaer, 1805)

MATERIAL. Kerkyra: 1 , Mt. Pantokrator, under stones in phrygana, 29.05.1999; 2 \%०, nr. Agios Stephanos, in old olive grove, 31.05-4.06.1999. LeFKADA: 1 , W of Mikros Ghialos, under stones, 27.05.1995.

DISTRIBUTION. From Europe to central Asia. Widespread and common in Greece.

\section{Theridion adrianopoli Drensky, 1915}

MATERIAL. Kerkyra: 1 , Mt. Pantokrator, under stones in phrygana, 29.05.1999; 1 $+\mathrm{S}$ of Avlaki, under stones in short turf, 2.06.1999. - LeFKADA: 19 , behind Mikros Ghialos, on rock face, 29.05.1995; 2 + 9 , W of Mikros Ghialos, among and under stones in maquis, 26-28.05.1995; 1 + , E of Mikros Ghialos, under stones, 3.06.1995. Det. B. Knoflach.

DISTRIBUTION. Croatia, Bulgaria, Greece and Turkey. Widespread in Greece. New to Lefkada.

\section{Theridion corcyraeum Brignoli, 1984}

MATERIAL. LEFKADA: 1 ㅇ, nr. Poros, under stones, 24.05.1995.

DISTRIBUTION. Originally described from Kerkyra and recently reported from Crete by Bosmans et al. [2013]. New to Lefkada.

\section{Theridion sp.}

MATERIAL. Kerkyra: $10^{7}$, Kerasia beach, nr. Agios Stephanos, in olive grove, 26.05.2000. Det. B. Knoflach.

COMMENTS. This species belongs to the T. melanurum group that is in need of complete revision in the Mediterranean region.

Theridion varians Hahn, 1833

MATERIAL. KerKyra: $10^{7}$, nr. Agios Stephanos, under stones in old olive grove, 1.06.2000. - LeFKADA: $1 \bigcirc^{7} 1$, valley $\mathrm{W}$ of Mikros Ghialos, beaten from shrubs, 25.05.1995.

DISTRIBUTION. A Holarctic species but with only a few scattered records from Greece. New to Lefkada. 


\section{Family THOMISIDAE}

\section{Heriaeus melloteei Simon 1886}

MATERIAL. Kerkyra: 1 , Kerasia beach, nr. Agios Stephanos, in olive grove, 28.05.2000; 2 우, house nr. Agios Stephanos, under stones, 3.06.1999. - LEFKADA: $1 \sigma^{7} 1$, Mikros Ghialos, in grass behind fishing port, 1.06.1995.

DISTRIBUTION. Europe to central Asia. Widespread in Greece.

Ozyptila confluens (C.L. Koch, 1845)

MATERIAL. LEFKADA: $19, \mathrm{~W}$ of Mikros Ghialos, under stones in maquis, 28.05.1995.

DISTRIBUTION. Southern Europe and Syria. Quite widely distributed in Greece.

Synema globosum (Fabricius, 1775)

MATERIAL. Kerkyra: 1 , Kerasia beach nr. Agios Stephanos, on ground in olive grove, 25.05.1999. — LEFKADA: $1 \sigma^{7}$, valley

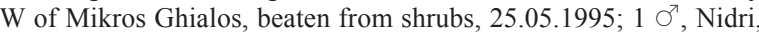
on rocks in gorge, 26.05.1995.

DISTRIBUTION. A Palaearctic species which is widespread and abundant in Greece, as elsewhere in the Mediterranean.

Thomisis onustus Walckenaer, 1805

MATERIAL. KerKyra: 1 , between Erivia and Lafkion, on ground in phrygana, 4.06.1999. - LeFKADA: $1+$, nr. Poros, beaten from shrubs in phrygana, 24.05.1995; $1 \sigma^{7}$, behind Mikros Ghialos, in grass, 1.06.1995.

DISTRIBUTION. A Palaearctic species widespread throughout the Mediterranean. Common throughout Greece.

Tmarus piochardi (Simon, 1866)

MATERIAL. Kerkyra: $10^{7}$, Kerasia beach nr. Agios Stephanos, on wall of house, 3.06.1999.

DISTRIBUTION. The Mediterranean from Spain to Turkey. Only a scattering of records from Greece and new to Kerkyra.

Tmarus stellio Simon, 1875

MATERIAL. KeRKyra: $1 \sigma^{7}$, Kerasia beach nr. Agios Stephanos, on wall of house, 3.06.1999.

DISTRIBUTION. A Palaearctic species distributed from Europe to Japan. This appears to be the first record for Greece.

Xysticus cor Canestrini, 1873

MATERIAL. LEFKADA: 1 + , Poros, under stones in phrygana, 24.05.1995.

DISTRIBUTION. Southern Europe. This is the first record for Greece.

Xysticus kempeleni Thorell, 1872

MATERIAL. KERKYRA: 1 , $\mathrm{S}$ of Avlaki, under stones in short turf, 2.06.1999.

DISTRIBUTION. From Europe to central Asia. In Greece there are only two previous records from Argolida in the Peloponnese [Hadjissarantos, 1936] and the island of Chios [Russell-Smith et al., 2011]. New to Kerkyra.

Xysticus tenebrosus Silhavy, 1944

MATERIAL. Kerkyra: 1 o $^{7} 2$ OPO, Kerasia beach, nr. Agios Stephanos, under stones in olive grove and below Eucalyptus,
28.05-6.06.2000; 1 ㅇ, Agios Stephanos, under stones in olive grove, 1.06 .1999

DISTRIBUTION. Recorded from Bosnia, Bulgaria and Greece. There are very few scattered records from Greece and it is new to Kerkyra.

\section{Family ULOBORIDAE}

\section{Uloborus walckenaerius Latreille, 1806}

MATERIAL. LefKADA: 2 OP, W of Mikros Ghialos, under stones in old olive grove, 23.05.1993; 1 \% , nr. Poros, beaten from shrubs in phrygana, 24.05.1995; 1 +, $\mathrm{W}$ of Mikros Ghialos, beaten from shrubs, 28.05.1995.

DISTRIBUTION. A Palaearctic species which is widespread and common in Greece. New to Lefkada.

\section{Family ZODARIIDAE}

Palaestina expolita O. Pickard-Cambridge, 1872

MATERIAL. LEFKADA: $1 \sigma^{\top}$, behind Mikros Gialos, on ground, 28.05.1993; $1 \mathrm{O}^{7}$, E of Mikros Gialos, under stones, 3.06.1993. Det. R. Bosmans.

DISTRIBUTION. Greece, Turkey, Israel and Lebanon. Only a few records from Greece and new to Lefkada.

\section{Zodarion graecum (C.L. Koch, 1843)}

MATERIAL. KeRKYRA: 2 O $^{\top} \sigma^{\top} 2$ 우, S of Avlaki, under stones in turf near beach, $3.06 .2000 ; 1$, Aghios Spiridou, under stones in old olive grove, 4.06.2000; 1 , Agni, under stones in olive grove, 2.06.2000. - LeFKADA: 1 , Mikros Gialos, under stones in olive grove, 23.05.1993; 1 을 behind Mikros Gialos, in grass, 3.06.1993; $1 \sigma^{7}$, W of Mikros Gialos, under stones, 28.05.1993. Det. R. Bosmans.

DISTRIBUTION. The Balkans, Greece, Turkey Ukraine, the Lebanon. Quite widespread in Greece but new to Kerkyra and Lefkada.

\section{Discussion}

In the present study, 94 species of spider were recorded from Kerkyra of which 37 were new to the island. With the 206 species previously recorded (Appendix 1), the total number of species known from Kerkyra is currently 243. From Lefkada: 98 species were recorded of which 71 were new to the island. With the 46 species previously recorded (Appendix 2), the total for Lefkada now stands at 117 species.

Among the species recorded, five were new to Greece. These include the linyphiids Agyneta mollis, Tenuiphantes herbicola (Lefkada) and Trichoncus sordidus (Kerkyra) as well as the thomisids Tmarus stellio (Kerkyra) and Xysticus cor (Lefkada).

How does the total numbers of species recorded in Kerkyra and Lefkada compare with such figures from other Greek islands? The recent survey of Lesbos (1632 $\mathrm{km}^{2}$ ) by Bosmans et al. [2009] gave a total of 300 fully identified species while a similar survey of Chios $(904$ $\mathrm{km}^{2}$ ) by Russell-Smith et al. [2011] gave a figure of 253 species.

On the assumption that the relationship between the area of each island and the number of species recorded 
is linear, we would expect approximately 165 species from Kerkyra and 86 species from Lefkada. However, laying aside the fact that this extrapolation is based on far too few data, we know that the relationship between island area and species richness is not linear but rather a power function which is fitted either by a logarithmic or semi-logarithmic curve [Preston, 1962]. In reality, it is more than probable that the number of species from both islands is significantly higher than the current totals suggest for a number of reasons:

a) The surveys of Lesbos and Chios are certainly incomplete. In particular, the authors of the latter survey [Russell-Smith et al., 2011] included a further 62 taxa, the systematic status of which had yet to be clarified.

b) Many arachnologists in the Ionian islands collected for relatively short periods in the year. For example, the present records were all obtained in the last week of May and first week of June. Species that matured before or after this period would not have been identified.

c) Much work in both islands appears to have been geographically restricted. Most records from Kerkyra are from the mountainous North of the island. The southern part of the island, which has important wetland and forest ecosystems, has hardly been visited (Map 1). Likewise, the mountainous interior of Lefkada is poorly recorded (Map 2).

Further survey work on both islands is undoubtedly needed before a complete picture of their spider faunas can be presented.

ACKNOWLEDGEMENTS. I wish to thank several colleagues who have identified or confirmed identifications of difficult specimens, including Angelo Bolzern (Agelenidae), Robert Bosmans (Linyphiidae and Zodariidae), Christa Deeleman-Reinhold (Dysderidae), Barbara Knoflach (Theridiidae) and Heiko Metzner and Dmitri Logunov (Salticidae). Their time and patience is truly appreciated. The author is particularly grateful to Rudy Jocqué for providing the maps of collecting localities on the two islands.

\section{References}

Ausserer A. 1871a. Beiträge zur Kenntniss der Arachniden-Familie der Territelariae Thorell (Mygalidae Autor) // Verh. zool.-bot. Ges. Wien. Bd.21. S.117-224.

Ausserer A. 1871b. Neue Radspinnen // Verh. zool-bot. Ges. Wien. Bd.21. S.815-832.

Bosmans R., van Keer J. 1999. The genus Enoplognatha Pavesi, 1880 in the Mediterranean region (Araneae: Theridiidae) // Bull. Br. arachnol. Soc. Vol.11. P.209-241.

Bosmans R., Chatzaki M. 2005. A catalogue of the spiders of Greece: A critical review of all spider species cited from Greece with their localities // Nieuwsbrief Belg. Arachnol. Vereniging. Supplement 2. Vol.20. P.1-124.

Bosmans R., Baert L., Bosselaers J., De Koninck H., Maelfait J.P., van Keer J. 2009. Spiders of Lesbos (Greece) // Nieuwsbrief van de Belgische Arachnologische Vereniging Vol.24. P.1-70.

Bosmans R., Van Keer J., Russell-Smith A., Kronestedt T., Alderweireldt M., Bosselaers J., De Koninck H. 2013. Spiders of Crete (Araneae). A catalogue of all currently known species from the Greek island of Crete // Newsletter Belg. Arachnol. Soc. Supplement 1. Vol.28. P.1-147.
Brignoli P.M. 1971. Beitrag zur Kenntnis der mediterranen Pholcidae (Arachnida, Araneae) // Mitt. zool. Mus. Berl. Bd.47. S.255-267.

Brignoli P.M. 1972. Su alcuni ragni cavernicoli di Corfù (Arachnida, Araneae) // Revue suisse Zool. T.79. P.861-869.

Brignoli P.M. 1974. Ragni di Grecia VI. Specie nuove o interessanti delle isole Ionie e della Morea (Araneae) // Revue suisse Zool. T.81. P.155-175.

Brignoli P.M. 1976. Ragni di Grecia IX. Specie nuove o interessanti delle famiglie Leptonetidae, Dysderidae, Pholcidae ed Agelenidae (Araneae) // Revue suisse Zool. T.83. P.539-578.

Brignoli P.M. 1977. Ragni di Grecia X. Nuovi dati sulla Grecia continentale ed insulare (Araneae) // Revue suisse Zool. T.84. P.937-954.

Brignoli P.M. 1979. Ragni di Grecia XI. Specie nuove o interessanti, cavernicole ed epigee // Revue suisse Zool. T.86. P.181202.

Brignoli P.M. 1984. Ragni di Grecia XII. Nuovi dati su varie famiglie (Araneae) // Revue suisse Zool. T.91. P.281-321.

Bristowe W.S. 1935. The spiders of Greece and the adjacent islands // Proc. zool. Soc. Lond. Vol.1934. P.733-788.

Chatzaki M., Thaler K., Mylonas M. 2002. Ground spiders (Gnaphosidae; Araneidae) of Crete and adjacent areas of Greece. Taxonomy and distribution. I // Rev. suisse Zool. T.109. P.559601.

Deeleman-Reinhold C.L., Deeleman P.R. 1988. Revision des Dysderinae (Araneae, Dysderidae), les especes mediterraneennes occidentales exceptees // Tijdschr. Ent. Vol.131. P.141-269.

Doleschall L. 1852. Systematisches Verzeichniss der im Kaiserthum Österreich vorkommenden Spinnen // Sitz.-ber. Akad. Wiss. Wien. Bd.9. S.622-651.

Giltay L. 1932. Arachnides recueillis par M. d'Orchymont au cours de ses voyages aux Balkans et en Asie Mineure en 1929, 1930 et $1931 / /$ Bull. Mus. roy. hist. nat. Belg. Vol.8. No.22. P.1-40.

Giltay L. 1933. Description des arachnides nouveaux recueillis par M. A. d'Orchymont aux Balkans et en Asie Mineure en 192931 // Acta fauna flora uni. Vol.1. No.3-5. P.1-8.

Grimm U. 1985. Die Gnaphosidae Mitteleuropas (Arachnida, Araneae) // Abh. naturw. Ver. Hamb. Bd.26. S.1-318.

Grimm U. 1986. Die Clubionidae Mitteleuropas: Corinninae und Liocraninae (Arachnida, Araneae) // Abh. naturw. Ver. Hamb. Bd.27. S.1-91.

Hadjissarantos H. 1940. Les araignées de l'Attique. Athens. 132 p.

Knoflach B. 1987. Zur Taxonomie, Verbreitung und Sexualbiologie von Theridion adrianopoli Drensky (Arachnida: Araneae, Theridiidae) // Ber. nat.-med. Verein Innsbruck. Bd.84. P.133-148.

Knoflach B. 1998. Mating in Theridion varians Hahn and related species (Araneae: Theridiidae) // J. nat. Hist. Vol.32. P.545-604.

Knoflach B. 1999. The comb-footed spider genera Neottiura and Coleosoma in Europe (Araneaem Theridiidae) // Mitt. schweiz. ent. Ges. Vol.72. P.341-371.

Kulczyński W. 1909. Fragmenta Arachnologica. XIV, XV // Bull. Acad. Cracovie. Vol.1909. P.667-687.

Koch L. 1867. Zur Arachniden und Myriapoden-Fauna Süd-Europas // Verh. zool.-bot. Ges. Wien. Bd.17. S.857-900.

Lecigne S. 2014. Contribution à l'inventaire aranéologique de Corfou (Grèce) (Arachnida, Araneae) // Nieuwsbr. Belg. Arachnol. Ver. Vol.28. No.3. P.177-191.

Metzner H. 1999. Die Springspinnen (Araneae, Salticidae) Griechenlands // Andrias Bd.14. S.1-279.

Muster C., Thaler K. 2004. New species and records of Mediterranean Philodromidae (Arachnida, Araneae): I. Philodromus aureolus group // In: Thaler K. (ed.), Diversität und Biologie von Webspinnen, Skorpionen und anderen Spinnentieren. Denisia. Vol.12. P.305-326.

Pickard-Cambridge O. 1870. Descriptions and sketches of two new species of Araneida, with characters of a new genus // J. Linn. Soc. Lond. (Zool.). Vol.10. P.398-405.

Pickard-Cambridge O. 1872. Descriptions of twenty-four new species of Erigone // Proc. zool. Soc. Lond. Vol.1872. P.747-769.

Pickard-Cambridge O. 1873. On some new species of European spiders // J. Linn. Soc. Lond. Vol.11. 530-547. 
Pickard-Cambridge, O. 1874. On some new species of Drassides // Proc. zool. Soc. Lond. Vol.1874. P.370-419.

Pavesi P. 1878. Nuovi risultati aracnologici delle Crociere del "Violante". Aggiunto un catalogo sistematico degli Aracnidi di Grecia // Ann. Mus. civ. stor. nat. Genova. Vol.11. P.337-396.

Preston F.W. 1962. The canonical distribution of commonness and rarity: Part I // Ecology. Vol.43. P.185-215.

Reimoser E. 1930. Araneae // Beier M. (ed.). Zoologische Forschungsreise nach den Jonischen Inselsn und dem Pelopennes. Sitz. Akad. Wissen. (math.-natur. Klasse) Wein. Bd.139. S. 143-154.

Reimoser E. 1958. Zoologische Studien in West-Griechenland // Sitz. Akad. Wissen. (math.-natur. Klasse) Wein. Bd.167. S.569-574.

Roewer C.F. 1962. Über einige mediterrane Arachniden // Fragm. ent. Vol.4. P.11-18.

Russell-Smith A., Allison A., Askins M., Blumsom W., Snazell R., Spilling C. 2011. A provisional checklist and gazetteer of the spiders of Chios, Greece (Arachnida: Araneae) // Bull. Br. arachnol. Soc. Vol.15. P.133-167.

Schröder M., Chatzaki M., Buchholz S. 2010. The spider fauna of the Aladjagiola wetland complex (Nestos Delta, north-east Greece): a reflection of a unique zoogeographical transition zone in Europe // Biol. J. Linn. Soc. Vol.102. P.217-233.

Senglet A. 2001. Copulatory mechanisms in Hoplopholcus, Stygopholcus (revalidated), Pholcus, Spermophora and Spermophorides (Araneae, Pholcidae), with additional faunistic and taxonomic data // Mitt. schweiz. ent. Ges. Bd.74. S.43-67.

Simon E. 1868. Monographie des espèces européennes de la famille des attides (Attidae Sundewall. - Saltigradae Latreille) // Ann. Soc. ent. Fr. Ser.4. Vol.8. P.11-72, 529-726.

Simon E. 1878. Etudes arachnologiques. 8e Mémoire. XI05. Liste des espèces européennes et algériennes de la famille des Attidae, composant le collection de Mr le co e Keyserling // Ann. Soc. ent. Fr. Ser.5. Vol.8. P.201-212.

Simon E. 1880. Liste d'Arachnides recueillis en Grèce par M. A. Letourneux // Ann. Soc. ent. Fr. Ser.5. Vol.10. P.139-140.

Simon E. 1884. Etudes arachnologiques. 16e Mémoire. XXIII. Matériaux pour servir à la faune des arachnides de la Grèce // Ann. Soc. ent. Fr. Ser.6. Vol.4. P.305-356.

Thaler K., Knoflach B. 1998. Two new species and new records of the genus Amaurobius (Araneae, Amaurobiidae) from Greece // Selden P.A. (ed.). Proceedings of the 17th European Colloquium of Arachnology, Edinburgh 1997. Edinburgh. P.107-114.

Van Keer J., Van Keer K., De Koninck H., Ramel G. 2010. The Arachnofauna (Araneae) of Wetland Kerkini (Macedonia-Northern Central Greece) // Acta zool. bulg. Vol.62. No.2. P.141-160.

\section{Appendix 1. List of spiders recorded from} Kerkyra prior to December 2013.

Agelenidae

Agelena orientalis C.L. Koch, 1837

Histopona hauseri (Brignoli, 1972)

Maimuna vestita (C.L. Koch, 1841)

Tegenaria ferruginea (Panzer, 1804)

Tegenaria pagana C.L. Koch, 1840

Tegenaria parietina (Fourcroy, 1785)

Tegenaria schoenhoferi Bolzern, Burckhardt et Hänggi, 2013 Amaurobiidae

Amaurobius erberi (Keyserling, 1863)

Amaurobius phaeacus Thaler et Knoflach, 1998

Amaurobius strandi Charitonov, 1937 Anapidae

Zangherella apuliae (Caporiacco, 1949) Anyphaenidae

Anyphaena sabina L. Koch, 1866 Araneidae

Agalenatea redii (Scopoli, 1763)
Araniella cucurbitina (Simon, 1757)

Araneus angulatus Clerck, 1757

Araneus circe (Audouin, 1826)

Argiope lobata (Pallas, 1772)

Cyclosa conica (Pallas, 1772)

Cyclosa insulana (Costa, 1834)

Cyclosa sierrae Simon, 1870 ?

Cyrtarachne ixoides (Simon, 1870)

Cyrtophora citricola (Forskål, 1775)

Gibbaranea bituberculata (Walckenaer, 1802)

Hypsosinga albovittata (Westring, 1851)

Mangora acalypha (Walckenaer, 1802)

Neoscona subfusca (C.L. Koch, 1837)

Singa semiatra L. Koch, 1867

Zilla diodia (Walckenaer, 1802)

Zygiella $x$-notata (Clerck, 1757)

Clubionidae

Clubiona leucaspis Simon, 1932

Clubiona vegeta Simon, 1918 Corinnidae

Phrurolithus festivus (C.L. Koch, 1835) Ctenizidae

Cyrtocarenum cunicularium (Olivier, 1811)

Cyrtocarenum grajum (C.L. Koch, 1836) Dictynidae

Dictyna latens (Fabricius; 1775)

Lathys humilis (Blackwall, 1855)?

Marilynia bicolor (Simon, 1870)?

Nigma flavescens (Walckenaer, 1830) ? Dysderidae

Dasumia nativitatis (Brignoli, 1974)

Dysdera circularis Deeleman-Reinhold, 1988

Dysdera corfuensis Deeleman-Reinhold, 1988

Dysdera crocata C.L. Koch, 1838

Dysdera murphiorum Deeleman-Reinhold, 1988

Dysdera pandazisi Hadjissarantos, 1940

Dysdera punctata C.L. Koch, 1838

Dysdera punctocretica Deeleman-Reinhold, 1988

Dysdera spinicrus Simon, 1882

Dysderocrates gasparoi Deeleman-Reinhold, 1988

Harpactea nausicaae Brignoli, 1976 Eresidae

Eresus kollari Rossi, 1846 Filistatidae

Filistata insidiatrix (Forskål, 1775) Gnaphosidae

Aphantaulax trifasciata (O. Pickard -Cambridge, 1872)

Berlandina corcyraea (O. Pickard-Cambridge, 1874)

Drassodes cupreus (Blackwall, 1834)

Drassodes lapidosus (Walckenaer, 1802)

Gnaphosa lucifuga (Walckenaer, 1802)

Haplodrassus signifer (C.L. Koch, 1839)

Nomisia exornata (C.L. Koch, 1839)

Pterotricha lentiginosa (C.L. Koch, 1837)

Scotophaeus blackwalli (Thorell, 1871)

Sosticus loricatus (L. Koch, 1866)

Zelotes cingarus (O. Pickard-Cambridge, 1874) Leptonetidae

Sulcia cretica violacea Brignoli, 1974 Linyphiidae

Agyneta pseudorurestris Wunderlich, 1980

Araeoncus humilis (Blackwall, 1841)

Bathyphantes gracilis (Blackwall, 1841)

Cresmatoneta mutinensis (Canestrini, 1868)

Diplocephalus graecus (O. Pickard-Cambridge, 1872)

Erigone dentipalpis (Wider, 1834) 
Erigonoplus simplex Millidge, 1979

Erigonoplus spinifemuralis Dimitrov, 2003 Frontinellina frutetorum (C.L. Koch, 1834) Lepthyphantes corfuensis Wunderlich, 1995 Neriene clathrata (Sundevall, 1830) Palliduphantes byzantinus (Fage, 1931) Palliduphantes istrianus (Kulczyn'ski, 1914) Prinerigone vagans (Audouin, 1826) Tenuiphantes tenuis (Blackwall, 1852) Liocranidae

Liocranum ochraceum L. Koch, 1867 Lycosidae

Alopecosa albofasciata (Brullé, 1832)

Alopecosa aculeata (Clerck, 1757)

Alopecosa cursor (Hahn, 1831)

Alopecosa pentheri (Nosek, 1905)

Arctosa cinerea (Fabricius, 1777)

Arctosa perita (Latreille, 1779) ?

Arctosa variana C.L. Koch, 1847

Hogna radiata (Latreille, 1817)

Lycosa praegrandis C.L. Koch, 1836

Pardosa atomaria (C.L. Koch, 1847)

Pardosa hortensis (Thorell, 1872)

Pardosa proxima (C.L. Koch, 1847)

Piratula latitans (Blackwall, 1841)

Trochosa terricola Thorell, 1856 Mimetidae

Ero aphana (Walckenaer, 1802)

Ero flammeola Simon, 1881

Ero furcata (Villers, 1789) Miturgidae

Cheiracanthium erraticum (Walckenaer, 1802)

Cheiracanthium mildei L. Koch, 1864 ? Oecobiidae

Oecobius cellariorum (Dugès, 1836)

Oecobius maculatus Simon, 1870 ?

Oecobius navus Blackwall, 1859

Uroctea durandi (Latreille, 1809) Oxyopidae

Oxyopes ramosus (Martini et Goeze, 1778) Palpimanidae

Palpimanus gibbulus Dufour, 1820

Palpimanus orientalis Kulczyn'ski, 1909 Philodromidae

Philodromus aureolus (Clerck, 1757)

Philodromus lividus Simon, 1875

Philodromus lunatus Muster et Thaler, 2004

Philodromus pinetorum Muster, 2009 ?

Philodromus pulchellus Lucas, 1846

Tibellus oblongus (Walckenaer, 1802) Pholcidae

Holocnemus pluchei (Scopoli, 1763)

Pholcus phalangioides (Fuesslin, 1775)?

Spermophora senoculata (Dugès, 1836)?

Stygopholcus photophilus Senglet, 1971 Pisauridae

Pisaura mirabilis (Clerck, 1757) Salticidae

Bianor albobimaculatus (Lucas, 1846)

Chalcoscirtus difficilis (Simon, 1868)

Chalcoscirtus infimus (Simon, 1868)

Cyrba algerina (Lucas, 1846)

Euophrys frontalis (Walckenaer, 1802) ?

Euophrys rufibarbis (Simon, 1868)

Evarcha arcuata (Clerck, 1757)?
Evarcha jucunda (Lucas, 1846)

Habrocestum graecum Dalmas, 1920 ?

Heliophanus cupreus (Walckenaer, 1802)

Heliophanus flavipes (Hahn, 1832)

Heliophanus kochii Simon, 1868

Heliophanus lineiventris Simon, 1868

Heliophanus melinus L. Koch, 1867

Heliophanus simplex Simon, 1868

Heliophanus tribulosus Simon, 1868

Macaroeris nidicolens (Walckenaer, 1802)

Marpissa nivoyi (Lucas, 1846)

Menemerus semilimbatus (Hahn, 1829)

Myrmarachne formicaria (De Geer, 1778)

Neaetha membrosa (Simon, 1868)

Neon levis (Simon, 1871)

Pellenes diagonalis (Simon, 1868)

Pellenes geniculatus (Simon, 1868)

Pellenes laevigatus (Simon, 1868)

Pellenes nigrociliatus (Simon, 1875)

Philaeus chrysops (Poda, 1761)

Phlegra bresnieri (Lucas, 1846)

Phlegra fasciata (Hahn, 1826)

Phlegra lineata (C.L. Koch, 1846)

Pseudeuophrys obsoleta (Simon, 1868)

Saitis graecus Kulczyn'ski, 1905

Salticus mandibularis (Simon, 1868)

Salticus mutabilis Lucas, 1846

Salticus propinquus Lucas, 1846

Salticus unicolor (Simon, 1868)

Salticus zebraneus(C.L. Koch, 1837)

Synageles dalmaticus (Keyserling, 1863)

Thyene imperialis (Rossi, 1846) Scytodidae

Scytodes thoracica (Latreille, 1802) Segestriidae

Ariadna insidiatrix Audouin, 1826

Segestria florentina (Rossi, 1790)

Segestria senoculata (Linnaeus, 1758) Sicariidae

Loxosceles rufescens (Dufour, 1820) Sparassidae

Micrommata virescens (Clerck, 1757)

Micrommata ligurina (C.L. Koch, 1845) Tetragnathidae

Metellina merianae (Scopoli, 1763)

Pachygnatha degeeri Sundevall, 1830

Tetragnatha extensa (Linnaeus, 1758) Theridiidae

Anelosimus vittatus (C.L. Koch, 1836)

Argyrodes argyrodes (Walckenaer, 1841)

Asagena phalerata (Panzer, 1801)

Crustulina scabripes Simon, 1881

Enoplognatha afrodite Hippa et Oksala, 1983

Enoplognatha penelope Hippa et Oksala, 1982

Enoplognatha quadripunctata Simon, 1884

Episinus truncatus Latreille, 1809 ?

Euryopis episinoides (Walckenaer, 1847)

Kochiura aulica (C.L. Koch, 1838) ?

Lasaeola prona (Menge, 1868)

Neottiura herbigrada (Simon, 1873)

Parasteatoda lunata (Clerck, 1757)?

Pholcomma gibbum (Westring, 1851)

Steatoda albomaculata (Degeer, 1778)

Steatoda bipunctata (Linnaeus, 1758)

Steatoda grossa (C.L. Koch, 1838)? 
Steatoda paykulliana (Walckenaer, 1805) Steatoda triangulosa (Walckenaer, 1802) Theridion adrianopoli Drensky, 1915

Theridion corcyraeum Brignoli, 1984

Theridion sp. cf. melanurum?

Theridion varians Hahn, 1833

Theridiosomatidae

Theridiosomma gemmosum (L. Koch, 1877) Thomisidae

Ozyptila blackwalli Simon, 1875

Ozyptila brevipes (Hahn, 1826)

Ozyptila confluens (C.L. Koch, 1845)

Runcinia grammica (C.L. Koch, 1837)

Synema globosum (Fabricius, 1775)

Thomisus onustus Walckenaer, 1805

Xysticus acerbus Thorell, 1872

Xysticus kochi Thorell, 1872

Xysticus laetus Thorell, 1875

Xysticus thessalicus Simon, 1916 Titanoecidae

Nurscia albomaculata (Lucas, 1846) Uloboridae

Uloborus walckenaerius Latreille, 1806 Zodariidae

Zodarion elegans (Simon, 1873)

Zodarion frenatum Simon, 1884 Zoridae

Zora armillata Simon, 1878

Zora parallela Simon, 1878

Zoropsidae

Zoropsis oertzeni Dahl, 1901

Appendix 2. List of spiders recorded from Lefkada prior to December 2013

Agelenidae

Tegenaria atrica C.L. Koch, 1843

Tegenaria parietina (Fourcroy, 1785) Amaurobiidae

Amaurobius erberi (Keyserling, 1863) Araneidae

Mangora acalypha (Walckenaer, 1802) Dictynidae

Dictyna arundinacea (Linnaeus, 1758)

Nigma walckenaeri (Roewer, 1951) Dysderidae

Dysdera crocata C.L. Koch, 1838 Eresidae

Eresus cinnaberinus (Olivier, 1789)

Eresus walckenaeri Brullé, 1832 Gnaphosidae

Drassodes lapidosus (Walckenaer, 1802)
Haplodrassus signifer (C.L. Koch, 1839)

Haplodrassus silvestris (Blackwall, 1833)

Zelotes longipes (L. Koch, 1866) Hahniidae

Hahnia candida Simon, 1875 Lycosidae

Alopecosa albofasciata (Brullé, 1832)

Arctosa perita (Latreille, 1799)

Lycosa praegrandis C.L. Koch, 1836

Pirata piscatorius (Clerck, 1757)

Trochosa terricola Thorell, 1856 Miturgidae

Cheiracanthium mildei L. Koch, 1864 Nemesidae

Nemesia caementaria (Latreille, 1799) Oonopidae

Oonopinus ionicus Brignoli, 1979

Orchestina simoni Dalmas, 1916

Silhouettella loricatula (Roewer, 1942) Oxyopidae

Oxyopes lineatus Latreille, 1806

Peucetia viridis (Blackwall, 1858) Palpimanidae

Palpimanus gibbulus Dufour, 1820 Philodromidae

Philodromus rufus Walckenaer, 1826

Tibellus macellus Simon, 1875

Tibellus oblongus (Walckenaer, 1802) Pholcidae

Holocnemus pluchei (Scopoli, 1763)

Pholcus phalangioides (Fuesslin, 1775) Salticidae

Carrhotus xanthogramma (Latreille, 1819)

Heliophanus tribulosus Simon, 1868

Philaeus chrysops (Poda, 1761)

Phlegra bresnieri (Lucas, 1846) Scytodidae

Scytodes thoracica (Latreille, 1802) Sicariidae

Loxosceles rufescens (Dufour, 1820)

Tetragnathidae

Metellina segmentata (Clerck, 1757)

Tetragnatha extensa (Linnaeus, 1758) Theridiidae

Euryopis margaritata (L. Koch, 1867)

Steatoda paykulliana (Walckenaer, 1805)

Thomisidae

Ozyptila confluens (C.L. Koch, 1845)

Runcinia grammica (C.L. Koch, 1837)

Synema globosum (Fabricius, 1775)

Thomisus onustus Walckenaer, 1805

Responsible editor D.V. Logunov 